\title{
SOBRE LOS SIGNIFICADOS DEL LAUREL Y SUS FUENTES CLÁSICAS EN LA EDAD MEDIA Y EL SIGLO DE ORO
}

\author{
JAVIER SALAZAR RINCóN \\ UNED La Seu d'Urgell (Lérida)
}

\section{INTRODUCCIÓN}

En la cultura greco-latina numerosos árboles y plantas tuvieron un valor sagrado, fueron objeto de cultos muy variados, y se convirtieron en atributos de las principales divinidades o en símbolo de sus actividades y virtudes, como recordó Virgilio en sus Bucólicas (VII, 61-64), en que escribe:

Populus Alcidae gratissima, uitis Iaccho,

Formosae myrtus Ueneri, sua laurea Phoebo;

Phylis amat corylos; illas dum Phyllis amabit,

Nec myrtus uincet corylos, nec laurea Phoebi ${ }^{1}$.

\begin{abstract}
${ }^{1}$ «El álamo es lo que más agrada a Alcides, la vid a Baco, a la hermosa Venus el mirto, su laurel a Febo; Filis ama los avellanos; mientras ellos sean el objeto del amor de Filis, ni el mirto vencerá a los avellanos, ni el laurel de Febo» (Citamos por Oeuvres de Virgile. Texte latin, edic. de F. Plessis y P. Lejay, Paris, Hachette, 1913, p. 59; y para la versión española, Publio VirgiLIo MARón, Bucólicas. Geórgicas. Apéndice virgiliano, edic. de Tomás Recio García y Arturo Soler Ruiz, Madrid, Gredos, Biblioteca Clásica Gredos, 1990, p. 204). En su Égloga III, Garcilaso toma casi al pie de la letra los versos de Virgilio: «El álamo de Alcides escogido / fue siempre, y el laurel del rojo Apolo; / de la hermosa Venus fue tenido / en precio y en estima el mirto solo» (GARCILASO DE LA VEGA, Obra poética y textos en prosa, edic. de Bienvenido Morros y estudio preliminar de Rafael Lapesa, Barcelona, Crítica, Biblioteca Clásica, 1995, p. 242). Fernando de Herrera lo corrobora en sus comentarios a la obra de Garcilaso, en que reproduce un fragmento de la traducción de las Bucólicas de Diego de Girón: «El álamo de Alcides fue escogido, / y de Baco la vid; de la hermosa / Venus el mirto, el lauro fue querido / de Apolo" (Garcilaso de la Vega y sus comentaristas. Obras completas del poeta acompañadas de los textos integros de los Comentarios de Brocense, Fernando de Herrera, Tamayo de Vargas y Azara, edic. de Antonio Gallego Morell, Madrid, Gredos, Biblioteca Románica Hispánica Textos, 1972, H-839, p. 593).
\end{abstract}


La vid y la hiedra, en efecto, fueron los principales atributos de Dionisos en Grecia y de Baco en Roma, que a menudo aparecen coronados con sus hojas, por lo que ambas plantas han venido a simbolizar las energías vitales, el placer, la liberación de los deseos, la primacía de los impulsos instintivos $^{2}$. El olivo estuvo consagrado a Atenea entre los griegos, Minerva de los romanos, y llegó a representar las cualidades y acciones propias de esta diosa: la fecundidad, la sabiduría y la luz del intelecto, el cultivo de las artes y la agricultura, la consecución de la victoria y el mantenimiento de la $\mathrm{paz}^{3}$. El arrayán, o mirto, ha sido durante largo tiempo un símbolo del amor, y ya en el mundo antiguo estuvo dedicado a Venus ${ }^{4}$, como recordó Sebastián de Covarrubias en su Tesoro de la lengua castellana, cuando señalaba que «esta planta, por su hermosura, su frescor y su blandura y por el suavíssimo olor de sus flores», fue consagrada a ella, entre otras razones «porque quando compareció en el juyzio con las otras diosas, Juno y Palas, iva coronada de mirto que dio mucha gracia y ayudó para vencer en la contienda de quál de las tres era más hermosa» 5 .

Y en cuanto al laurel, ciñéndonos especialmente al ámbito de la literatura española, en el presente trabajo examinaremos los significados que adquirió en la Antigüedad, y que conservó, con pocas variaciones, en la Edad Media, una época en que la tradición pagana de Grecia y Roma se mantiene viva en los ambientes cultos y convive en armonía con el Cristianismo, y sobre todo en el Renacimiento, el periodo en que la cultura clásica conoce un nuevo y espléndido despertar.

\section{EL LAUREL, EL FUEGO Y EL DON DE LA PROFECÍA}

Por ser un árbol apto para provocar la ignición mediante el frotamiento, y por la capacidad que desde antiguo se le atribuía para suscitar sueños proféticos, los griegos y romanos consagraron el laurel a Apolo, la divinidad solar protectora de la sabiduría, la creación artística, la poesía,

\footnotetext{
${ }^{2}$ Jean Chevalier y Alain GheERBRANT, Diccionario de los símbolos, Barcelona, Herder, 2." edic., 1988, p. 564; y José Luis MORALES Y MARín, Diccionario de iconología y simbología, Madrid, Taurus, 1984, p. 123.

${ }^{3}$ Carlos Mendoza, La leyenda de las plantas. Mitos, tradiciones, creencias y teorías relativas a los vegetales, Barcelona, Biblioteca de "La Ilustración Ibérica», s. f., y edición facsímil, Barcelona, Alta Fulla, 1993, pp. 241-246; y J. CHEVALIER Y A. GHEERBRANT, Diccionario, pp. 148-149 y 775-776.

${ }^{4}$ Angelo DE GUBERNATIS, La mythologie des plantes. Les légendes du règne végétal, Paris, Reinwald, 1878, 2 vols., vol. I, pp. 293-294; y J. L. MORALES Y MARíN, Diccionario, p. 26.

${ }^{5}$ Sebastián DE CovarRubias, Tesoro de la Lengua Castellana o Española [1611], Madrid, Turner, 1979, p. 148.
} 
la música y las artes adivinatorias, como recordó Pérez de Moya, siguiendo a Fulgencio (Mithologicarum Liber I), en su Philosofía secreta:

Dedicáronle el laurel, porque frotando dos palos secos deste árbol uno con otro se enciende fuego, o porque puestas sus hojas sobre la cabeza del que duerme, ensueña, según dice Serapión, cosas verdaderas, que es género de adivinanza, arte atribuida a Apolo, o porque fingen haberlo Apolo recibido por su árbol, cuando en él se convirtió Daphne, su amiga ${ }^{6}$.

El doctor Andrés Laguna, en su comentario a Dioscórides, explica que el laurel tiene «en sí virtud de produzir fuego. Porque si fregamos dos palos de laurel secos uno con otro, y les echamos encima un poco de açufre puluerizado, súbito se alça la llama» ${ }^{7}$. También Fernando de Herrera, en sus comentarios a la obra de Garcilaso de la Vega, recuerda que:

\begin{abstract}
Consagraron los antiguos este árbol a Apolo porque está lleno de fuego, y Apolo, que es el Sol, es fuego, y dicen que no cae rayo donde hay laurel, y también que presiente lo que está por venir; porque ninguna cosa arde con tanto estruendo, como dice Lucrecio, y primero que él Teócrito. De donde los antiguos juzgaban los sucesos venideros, como refiere Porfirio; porque si cuando se quemaba, ardía con ruido, creían que denotaba felicidad, y así dijo Tibulo: At laurus bona signa dedit, gaudete coloni. Pero si se encendía callada, era triste agüero, y de esto dijo Propercio: Et iacet extincto laurus adusta foco $^{8}$.
\end{abstract}

En efecto, por ser Apolo el dios de la profecía, en los oráculos existía la costumbre de arrojar hojas de laurel al fuego, y si crepitaban era un buen augurio, mientras que, si ocurría lo contrario, era señal de sucesos nefastos; $\mathrm{y}$, tras consultar al oráculo del dios en Delfos, los griegos regresaban coronados de laurel cuando la respuesta recibida era halagüeña ${ }^{9}$. Alciato recuerda en sus emblemas que el laurel conoce el porvenir, trae señales de salvación futura $\mathrm{y}$, teniéndolo cerca por la noche, proporciona sueños que a la larga son verídicos: «Praescia venturi Laurus, fert signa salutis. Subdita pulvillo somnia vera facit» ${ }^{10}$. La misma idea, tomada de la tradición clásica, la expone Pérez de Moya en su Philosofía, como acabamos de ver; y Juan de Mal Lara, en su Descripción de la galera real

\footnotetext{
${ }^{6}$ Juan PÉREZ DE MOYA, Philosofía secreta de la gentilidad [1585], edic. de Carlos Clavería, Madrid, Cátedra, Letras Hispánicas, 1995, pp. 257-258.

${ }^{7}$ Andrés Laguna, Pedacio Dioscórides Anazarbeo, acerca de la materia medicinal $y$ de los remedios mortíferos, Salamanca, 1566, y edic. facsímil, Barcelona, MRA, 1994, 2 vols., vol. I, p. 65.

${ }^{8}$ Garcilaso de la Vega y sus comentaristas, edic. cit., p. 351.

${ }^{9}$ Carlos Mendoza, La leyenda, pp. 229-233; J. Chevalier Y A. Gheerbrant, Diccionario, p. 630; y J. L. MORALES Y MARín, Diccionario, p. 204-205.

${ }^{10}$ Alciato, Emblemas [1531], edic. de Santiago Sebastián, Madrid, Akal, 2. a edic., 1993, emblema CCX, p. 251.
} 
del serenísimo señor don Juan de Austria, tras evocar la leyenda de Dafne, tal como aparece narrada en la Metamorfosis, añade:

Tenían los antiguos que el laurel era contra los demonios y que encendida les daba fuerzas para adivinar: declaraban con el laurel sanidad y cordura, que son cosas que habemos de pedir de veras a Dios ${ }^{11}$.

\section{El LAUREL, SÍMBOLO DEL TRIUNFO MILITAR}

Aunque primitivamente las hojas de laurel coronaban a los sacerdotes de Apolo y a los poetas, como veremos después, con el paso de los siglos, especialmente entre los romanos, sus ramas acabaron simbolizando la gloria, especialmente la que se obtiene en la guerra con el triunfo, y en la paz mediante el ejercicio del poder, por lo cual el laurel se usó para coronar a los generales invictos y también a los emperadores, y para adornar las lanzas de los soldados, las proas de las naves victoriosas, o a los mensajeros, cartas y tablillas que traían buenas nuevas ${ }^{12}$ :

El laurel propiamente se dedica a los triunfos, y es gratíssimo en las entradas de las Casas de los Césares y Pontífices: y sólo él adorna las mismas Casas, y es como centinela delante de los umbrales [recordaba Plinio en el libro XV de su Historia Natural]. [...] Los Romanos le tienen por mensagero de alegría y de victoria, poniéndole con las cartas, y en las lanças de los soldados, y en los sombreros. Adorna las fasces de los Emperadores. Desde ellas se pone en el regaço de Júpiter Óptimo Máximo todas las vezes que alguna nueua victoria trae alegría. Y esto no porque siempre está verde, ni porque es árbol pacífico, que en vno y otro se ha de dar ventaja a la oliua; sino porque es bellísimo en el monte Parnaso. $\mathrm{Y}$ por esto también es agradable a Apolo ${ }^{13}$.

El laurel es signo de victoria y gloria en muchos textos latinos, y en sus Etimologías (XVII, 7, 2), San Isidoro, que hace derivar su nombre del vocablo laus (alabanza), recordaba que las ramas del laurel, por su verdor perenne, coronaban las cabezas de los vencedores:

Laurus a verbo laudis dicta; hac enim cum laudibus victorum capita coronabantur. Apud antiquos autem laudea nominabatur; postea $D$ littera sublata et subrogata $R$ dicta est laurus [...]. Hanc arborem Graeci $\delta \alpha ́ \phi v \eta v$ vocant, quod nunquam deponat viriditatem; inde illa potius victores coronantur ${ }^{14}$.

\footnotetext{
"Ana María ARAncón, Antología de humanistas españoles, Madrid, Editora Nacional, 1980 , p. 465

12 J. L. MORALES Y MARÍn, Diccionario, p. 204.

${ }^{13}$ Cayo Plinio Segundo, Historia natural, lib. XV, cap. 30, traducción, con escolios y anotaciones, de Gerónimo de la Huerta, Madrid, 1629, y edic. facsímil, Madrid, Instituto Geológico y Minero de España, 1982, 2 vols., vol. II, pp. 79-80.

${ }^{14}$ SAN Isidoro DE SEvilla, Etimologías, edic. bilingüe de José Oroz Reta y Manuel A. Marcos Casquero, Madrid, Biblioteca de Autores Cristianos, 1982, 2 vols., vol. II, p. 338 .
} 
Como ha señalado Curtius, la Edad Media conservó viva la asociación entre el laurel y la gloria militar, y en las epopeyas, el árbol suele ocupar un importante lugar como elemento de un paisaje ideal y como símbolo ${ }^{15}$ : Los caudillos se reúnen a deliberar bajo un laurel en el verso 2651 de la Chanson de Roland. En el Alexandreis de Gautier de Châtillon (II, 308), el campamento se levanta en un cerro donde hay un laurel ${ }^{16}$, y en nuestro anónimo Libro de Alexandre, antes de enfrentarse con Darío, los griegos acampan en un auténtico vergel situado en un montículo y presidido por el árbol símbolo de la victoria:

\section{Estávale en medio un laurel muy ançiano, las ramas muy espessas e el tronco muy sano; cubrié toda la tierra un vergel muy loçano, siempre estava verde ivierno e verano ${ }^{17}$.}

La idea tuvo además su plasmación en numerosos tratados de retórica y poética durante toda esta época: Inspirándose en los versos con que Virgilio pensaba iniciar la Eneida, y en los que alude a sus principales obras, los autores medievales elaboraron la teoría de los tres estilos (humilis, mediocris, gravis), a cada uno de los cuales corresponden distintas obras y géneros, e incluso distintas realidades o símbolos de carácter material, los árboles entre ellos; y así, al estilo humilde pertenecen las Bucólicas, el pastor, el cayado, la oveja, el prado y el haya; al estilo mediocre, las Geórgicas, el campesino, el arado, el buey, el sembrado y el árbol frutal; y al estilo grave o elevado, propio de poemas épicos como la Eneida, el guerrero, la espada, el caballo, el castillo, y el cedro y el laurel entre los árboles ${ }^{18}$.

Como signo del triunfo militar, la corona de laurel aparece repetidamente en la literatura del Renacimiento y el Barroco: En uno de sus emblemas, Andrea Alciato explica acerca del laurel, del que considera merecedor a Carlos $\mathrm{V}$ por su campaña de Túnez, que es la insignia del soldado victorioso: «Debetur Carlo superatis laurea Poenis: Victrices ornent talia serta comas» ${ }^{19}$. Y el doctor Andrés Laguna escribe:

Consagraron el laurel los antiguos al dios Apolo: con él se coronauan en los tiempos passados todos los emperadores de Roma, para el qual effecto (según

${ }^{15}$ Ernst Robert CuRTIUS, Literatura europea y Edad Media latina, México, Fondo de Cultura Económica, 1955, 2 vols., vol. I, pp. 280 y ss.

${ }^{16}$ Ibíd., p. 287 y n.

${ }^{17}$ Libro de Alexandre, edic. de Jesús Cañas, Madrid, Cátedra, Letras Hispánicas, 1988, estrofa 936, p. 307.

${ }^{18}$ Ernst Robert CURTIUS, Literatura europea, vol. I, pp. 287 y 328.

${ }^{19}$ AlCIATO, Emblemas, edic. cit., p. 251. Véase William S. HECKSCHER , «Andrea Alciati's Laurel Tree and its Symbolic Traditions», Emblematica. An Interdisciplinary Journal of Emblem Studies (New York), VI 2, 1992, pp. 207-218. 
cuentan las romanas historias) un águila enbiada de Iupiter, dexó caer en el regaço de Drusila, muger de Augusto, una gallina muy blanca, la qual lleuaua en el pico un ramillo de laurel, cargado de vayas muy olorosas, el qual plantado multiplicó después en grande abundancia. Coronauan también con laurel antiguamente a todos los vencedores; y como el Olivo era señal de paz, ansí siempre el laurel significaua victoria ${ }^{20}$.

También Fernando de Herrera, comentando a Garcilaso, recordó que las primeras coronas fueron de álamo blanco, y más tarde de diversas flores:

\begin{abstract}
Mas después que se dio esta honra a los poetas, se coronaron de lauro, hiedra y mirto. Luego salieron las coronas militares, y así como algún soldado acababa con virtud y fortaleza de ánimo alguna hazaña ilustre, así era remunerado con varias coronas; pero la primera entre todas era la triunfal, que se daba por ley en Roma al capitán que había muerto en batalla no menos que cinco mil contrarios. Ésta era lạ misma que la láurea común, sino que se elegía de las hojas mayores y de las bayas pendientes de ellas. Porque la popular era de las hojas del lauro común y simple, y no estaba tejida de las bayas ${ }^{21}$.
\end{abstract}

En la Égloga II de Garcilaso, Albanio, el pastor desdeñado por Camila que según la crítica es un trasunto del hermano menor del duque de Alba, don Bernaldino de Toledo ${ }^{22}$, contempla su propia imagen coronada de laurel en las aguas de una fuente, con lo que el autor recuerda su condición de militar y noble, y también sus similitudes con Apolo, el dios privado de su amor, la ninfa Dafne, convertida a su vez en un laurel:

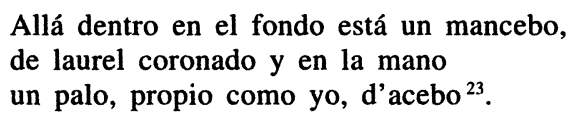

En la Égloga II, al evocar la victoria del duque de Alba don Fernando sobre los turcos, Garcilaso recuerda la costumbre romana, atestiguada entre otros por Virgilio (Geórgicas, I, 303-304) ${ }^{24}$, de colocar coronas de flo-

${ }^{20}$ Andrés Laguna, Pedacio Dioscórides, edic. cit., vol. I, p. 65.

${ }^{21}$ Garcilaso de la Vega y sus comentaristas, edic. cit., p. 562.

${ }^{22}$ Rafael LAPESA, La trayectoria poética de Garcilaso, Madrid, Alianza Editorial, 1985 , p. 110.

${ }^{23}$ Garcilaso DE LA Vega, Obra poética, edic. cit., p. 184. Además de las posibles significaciones del pasaje que hemos comentado, Bienvenido Morros señala que en el mundo clásico los locos aparecen coronados con vid, y en ocasiones con laurel, y que las hojas de este árbol, al quemarlas, aportaban salud y eran un antídoto contra la locura (Ibid., p. 184 n., y pp. 494-495).

${ }_{24}{ }$ Ceu pressae cum jam portum tetigere carinae, / Puppibus et laeti nautae imposuere coronas» [«A la manera que, cuando las naves cargadas han tocado ya puerto, colocan alegres los marineros coronas en la popa»] (Oeuvres de Virgile, edic, cit., p. 113; y Publio Virgilio MARón, Bucólicas. Geórgicas, edic, cit., p. 275). Con mayor libertad, Fray Luis de León, en su versión de la Bucólicas, traduce: «como cuando con viento al fin derecho / entran el puerto dulce y deseado / cargados los navíos de provecho, / ale- 
res en la proa de los barcos como signo de alegría, o de laurel en señal de triunfo:
Tras esto blanqueaba falda y seno con velas, al Tirreno, del armada sublime y ensalzada y gloriosa. Con la prora espumosa las galeras, como nadantes fieras, el mar cortan hasta que al fin aportan con corona de lauro a Barcelona ${ }^{25}$.

En la elegía que Cervantes dedica al cardenal Diego de Espinosa, ya repuesta del dolor y consolada con su poder político y militar:
De hoy más deje dẹl llanto la fiereza el afligida España, levantando con verde lauro ornada la cabeza ${ }^{26}$.

En uno de los dos sonetos que don Juan de Arguijo dedica al mito de Dafne, el laurel, como símbolo de gloria, prevalece sobre el olivo y la palma, las dos especies vegetales con significados similares:
L'antigua palma y l'abundosa oliva
a ti de hoy más inclinarán su gloria;
tú ceñirás en premio de victoria
d'el fuerte vencedor la frente altiva ${ }^{27}$

En el epitafio que Francisco de Quevedo escribe para don Pedro de Girón, duque de Osuna, recuerda que, tras ser destituido como virrey de Nápoles:

Sacó del remo más de dos mil fieles, y turcos puso al remo mil personas.

\footnotetext{
gres con laurel los marineros / coronan a los árboles veleros» (FRAY LUIS DE LEÓN, Obras completas castellanas, edic. del P. Félix García, Madrid, Biblioteca de Autores Cristianos, $4^{2}$ edic., 1967, 2 vols., vol. II, p. 894). También utilizó Lope la imagen en su Filomena, en la escena en que Tereo trata de persuadir a ésta para que le acompañe a Tracia junto a su hermana, y «las coronadas barcas le describe, / de tendales de seda y de triunfantes / laureles, que en la mar forman pensiles / en popas de cristales y marfiles» (Lope DE VEGA, Obras poéticas, edic. de José Manuel Blecua, Barcelona, Planeta, Clásicos Universales, 1983, p. 587).

${ }^{25}$ GaRCilaso De LA VeGA, Obra poética, edic. cit., p. 216.

${ }^{26}$ Miguel DE Cervantes, Poesias sueltas, en Obras completas, edic. de Ángel Valbuena Prat, Madrid, Aguilar, 1986, $18^{\text {a }}$ edic., 2 vols., vol. I, p. 45.

${ }^{27}$ Juan DE ARGUiJo, Obra poética, edic. de Stanko B. Vranich, Madrid, Castalia, Clásicos Castalia, 1972, p. 73.
} 
¡Y tú, bella Partépone, aprisionas

la frente que agotaba los laureles! ${ }^{28}$

Y en el romance que Estebanillo González ofrece al Cardenal Infante don Fernando con motivo de su cumpleaños:

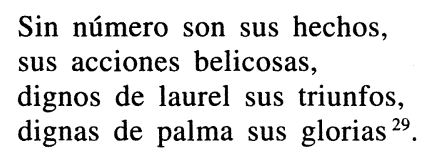

En el teatro barroco es frecuente la presencia del laurel, tanto en el texto como en el aderezo de la escena, para simbolizar la gloria, el triunfo, el poder. Entre las comedias de Lope recordaremos El Brasil restitui$d o$, en que se celebra la recuperación en 1626 de la ciudad de Bahía de Brasil, ocupada por los holandeses y reconquistada por las tropas españolas, y en cuya última jornada, el Brasil y la Religión premian a don Fadrique de Toledo mientras aquél pronuncia estas palabras:

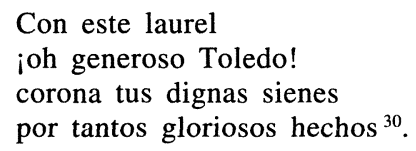

Y en el teatro de Calderón, la presencia de tales ornamentos es constante: Así, en la segunda jornada de La vida es sueño, Segismundo es conducido a palacio para que en él, según explica Clotaldo, «el soberano laurel / corone tu augusta frente» ${ }^{31}$. Basilio, en la última escena del drama, dirigiéndose a su hijo: «A ti el laurel y la palma / se te deben; tú venciste; / corónente tus hazañas» ${ }^{32}$. Y en la primera jornada de La hija del aire, Lisías recibe con estas palabras al rey Nino, que regresa victorioso:

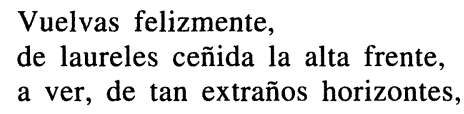

${ }^{28}$ Francisco DE QUEvedo, Poesía original completa, edic. de José Manuel Blecua, Barcelona, Planeta, Clásicos Universales, 1981, pp. 292-293.

${ }^{29}$ La vida y hechos de Estebanillo González [1646], edic. de Juan Millé y Giménez, Madrid, Espasa-Calpe, Clásicos Castellanos, 1956, 2 vols., vol. II, p. 110.

${ }^{30}$ Lope DE VEGA, Obras, edic. de Juan Eugenio Hartzenbusch y Marcelino Menéndez y Pelayo, Madrid, Atlas, 1970, 33 vols., vol. 28 (Biblioteca de Autores Españoles, 233), p. 296.

31 Pedro CAlderón DE LA BARCA, Obras, edic. de Juan Eugenio Hartzenbusch, Madrid, Atlas, 1944-1945, 4 vols. (Biblioteca de Autores Españoles, 7, 9, 12, 14), vol. I, p. 7.

${ }^{32}$ Ibid., p. 18. 
hoy, gran señor, aquestos patrios montes que ausente te han tenido edades tantas ${ }^{33}$.

En las novelas y relatos cortos del siglo XVII, la corona de laurel cumple una función similar como signo de la gloria o del poder, aunque éste sea tan efímero como el de Narcisa, reina temporal de los festejos organizados en el cigarral toledano, la cual transfiere el trono a don Juan en una refinada ceremonia cortesana en la que:

Cenaron, acompañando al deleite del gusto el del oído, recreado con músicas y letras, unas alegres y otras artificiosas, siendo el último plato que se sirvió una corona de laurel, que recibiéndola Narcisa, y honrándola en la cabeza de don Juan, dijo, quitándose la suya:

— «Ya yo he cumplido con el gobierno que sin merecimientos (hermosas damas y gallardos caballeros) os he usurpado» [...].

— «Dudoso admito el laurel con que me honráis, pródiga señora (respondió el futuro Rey), de vos por tantas razones merecido, pues si de todo gobierno se espera que ha de aventajarse al pasado, habiendo el vuestro agotado a la posibilidad y al ingenio la esperanza de igualarle, ¿qué ha de hacer quien se ve obligado por las leyes a sucederos, y por la cortedad se imposibilita de imitaros?» ${ }^{34}$

Y en una de las novelas de doña María de Zayas, en otra reunión de caballeros y damas:

Las cuatro de la tarde serían, cuando empezaron a salir las damas desengañadoras, tan vistosas y aderezadas y con tanta bizarría, que sólo en verlas se tuvieron por satisfechos de lo que habían aguardado. Venían delante Laura y doña Luisa, que, como viudas, no pudieron mudar traje, con sus vestidos negros y tocas albísimas, y en sus cabezas dos coronas de laurel, y tras las otras damas, todas vestidas de encarnado, con muchas joyas; las cabezas, muy aseadas, y encima de los tocados las mismas coronas, como vencedoras triunfantes, y detrás de todas salió la discreta Lisis ${ }^{35}$.

En fin, un cierto contagio petrarquista lleva a algunos poetas del Renacimiento y el Barroco a aprovechar el significado triunfal del árbol en poemas en que el laurel ya no es el emblema del triunfo militar, sino del triunfo amoroso. Así, en el soneto CXVI de Boscán — «Amor m'enbía un dulce sentimiento»-, y siguiendo los pasos de Petrarca — «Amor mi manda quel dolce pensero» ${ }^{36}$-, el alma resucita y queda glorificada al recibir el soplo mágico del verdadero amor, tras lo cual:

\footnotetext{
${ }^{33}$ Ibíd., vol. III, p. 24.

${ }^{34}$ TiRso DE Molina, Cigarrales de Toledo [1624], edic. de Luis Vázquez Fernández, Madrid, Castalia, Clásicos Castalia, 1996, p. 272.

${ }^{35}$ María DE ZAYAS, Parte segunda del sarao y entretenimiento honesto. Desengaños amorosos [1647], edición de Alicia Yllera, Madrid, Cátedra, Letras Hispánicas, $3^{\mathrm{a}}$ edic., 1998, p. 404

${ }^{36}$ Francesco PETRARCA, Cancionero, «Soneto CLXVIII», edición bilingüe de Jacobo Cortines, Madrid, Cátedra, Letras Universales, 1989, 2 vols., vol. II, p. 566.
} 
Celebrado seré de toda gente, llevando en mi triumpho para'l cielo con el verde laurel la blanca palma ${ }^{37}$.

Mientras que en la carta que comienza «Amor, Amor, que consientes», de don Diego Hurtado de Mendoza, el laurel corona la frente de la amada, que ha burlado con su menosprecio los deseos del enamorado:

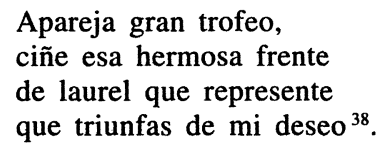

\section{EL LAUREL Y LA GLORIA LITERARIA}

Sin embargo, Apolo, a quien el laurel estaba dedicado, fue entre los antiguos, por encima de otras consideraciones, el dios protector de la poesía, la música y las demás artes, y por tal motivo, y por su verdor perenne, su árbol simbolizaba originariamente el triunfo y la gloria en general, y especialmente la que se consigue en el campo de las artes y el saber, un significado que va a prevalecer en la Edad Media y el Renacimiento. En la obra de Petrarca, por ejemplo, el laurel suele tener como referente casi exclusivo a su amada Laura, o al amor que su presencia o su recuerdo despiertan, como veremos después, aunque también sus ramas son en ocasiones el signo de la gloria inmortal que el poeta alcanza con sus escritos. Así, en la composición CXIX de su Cancionero, escrita con motivo de la coronación del autor en Roma, el 8 de abril de 1341, ante el poeta aparece la Gloria - «Una donna piú bella assai che l'sole»-, la cual, en la penúltima estrofa, «di verde lauro una ghuirnalda colse, / la qual co le sue mani / intorno intorno a le mie tempie avolse» ${ }^{39}$. También Petrarca aprovecha los significados tradicionales del laurel, la palma y el olivo - gloria, triunfo y paz respectivamente- en el soneto CCXXX de su Cancionero, cuando el poeta, anegado en un río de lágrimas, ruega a la Piedad:

\footnotetext{
37 Juan Boscán, Obra completa, edic. de Carlos Clavería, Madrid, Cátedra, Letras Hispánicas, 1999, pp. 227-228.

${ }^{38}$ Diego Hurtado De Mendoza, Poesía completa, edic. de José Ignacio Díez Fernández, Barcelona, Planeta, Clásicos Universales, 1989, p. 178.

${ }^{39}$ «y de verde lauro una guirnalda / cogió con sus dos manos / y me la puso en torno de las sienes» (Francesco PeTrarca, Cancionero, edic. cit., vol. I, pp. 436-437). Para la presencia del laurel como símbolo en la poesía de Petrarca, y sus imitaciones en poetas posteriores, véase María Pilar MANERo SOROLla, Imágenes petrarquistas en la lírica española del Renacimiento. Repertorio, Barcelona, PPU, 1990, pp. 358 y ss. La autora ofrece además numerosos ejemplos de la presencia del laurel como emblema de la gloria en la obra latina del autor (Ibíd., p. 362, n. 418).
} 
Non lauro o palma, ma tranquilla oliva

Pietà mi manda, e ' 1 tempo rasserena,

e ' 1 pianto asciuga, et vuol anchor ch'i' viva ${ }^{40}$.

Y en la canción CCCLIX, el alma de su amada Laura vuelve desde el cielo llevando en su seno «un ramoscel di palma / et un di lauro», cuya significación, que coincide con la que hemos indicado, ella misma explica al desconsolado amante:

palma è victoria, et io, giovene anchora, vinsi il mondo et me stessa; il lauro segna trïumpho, ond'io son degna,

mercé di quel Signor che mi die' forza ${ }^{41}$.

Juan de Mena, en su Tratado del título de duque, recuerda que el serto o corona hecha con palma o laurel «denota la grand sobreza e destreza de la guerra con la qual vençió e vino victorioso de sus enemigos», mientras que:

Laureola se llama otra corona que pertenesçe a los poetas e ésta ha de ser de laurel, e fue antiguamente introduzida porque este árbol de laurel fue dedicado e atribuido entre los gentiles al dios Febo, que entre ellos fue avido por dios del saber, e por ende de aquel árbol resçibían corona los sçientes poetas $^{42}$.

En el preámbulo tercero de su Coronación del marqués de Santillana, Mena se limita a anotar la segunda significación del laurel, cuando explica que el Marqués merecía una corona compuesta:

...de fojas e de ramas de dos árvoles: de laurel, porque denota alabança e gloria de sabiduría, de las quales fueron coronados Vergilio, Omero, Ovidio e otros; otrosí es coronado de ramas e corona de robles, que denota feroçidad e valentía e esperto conosçimiento de la militar diçiplina ${ }^{43}$.

${ }^{40}$ «Ni palma ni laurel, sereno olivo / envíame Piedad, y el tiempo aquieta, / y el llanto enjuga, y quiere que yo viva» (Ibíd., vol. II, pp. 702-703).

${ }^{41}$ «la palma es la victoria, y aún yo joven / a mí vencí y al mundo; triunfo indica / este laurel, y digna / soy gracias al Señor, que me dio fuerzas» (Ibíd., vol. II, pp. 10021005).

42 Juan DE MENA, Obras completas, edic. de Miguel Ángel Pérez Priego, Barcelona, Planeta, Clásicos Universales, 1989, p. 402.

${ }^{43}$ Ibid., p. 108. En el comentario de la estrofa XXXIII del mismo libro, siguiendo a San Isidoro, el autor añade: «...laurel traxo este nombre desta palabra laus, por alabança, e de aqueste árbol en otro tienpo coronavan a los poetas, e los antiguos laudea le solían llamar en latín, e por antigüedad fue sublata aquella letra $d$ e llámanlo laurus, e este árbol los griegos llaman dafnen, que quiere decir árbol que siempre dura verde, e por ende los poetas en otro tiempo solían ser coronados a esta semejança de las ramas de aquel árbol, que así como el laurel siempre dura verde así la fama de los poetas nunca se seca nin pereçe» (Ibíd., p. 181). 
El marqués de Santillana, por su parte, imagina coronado con laurel al poeta Jordi de Sant Jordi por mano de la diosa Venus, la cual, tras aceptar el ruego de Homero, Lucano y Virgilio para que el poeta valenciano «resçiba la corona / de los discretos letrados», exclama:

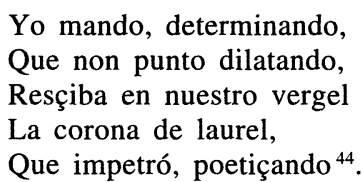

$\mathrm{Y}$ en la visión en que el poeta contempla a Bocaccio:

$$
\begin{aligned}
& \text { Después de las quales, vi más: vn varón } \\
& \text { En hábito honesto, mas bien arreado, } \\
& \text { Y non se ignoraua la su perfeción, } \\
& \text { Ca de verde lauro era coronado }{ }^{45} \text {. }
\end{aligned}
$$

La presencia del laurel como insignia del triunfo literario va a ser muy corriente durante el Renacimiento, y así, en la elegía que Mosquera de Figueroa dedica a la muerte de Garcilaso, las ramas con que se corona a los poetas aparecen suplantadas por un árbol funerario:

$$
\begin{aligned}
& \text { Publíquese el dolor a los sentidos } \\
& \text { y en lugar del laurel que en vos florece } \\
& \text { salga el ciprés con ramos esparcidos }{ }^{46} \text {. }
\end{aligned}
$$

En la canción del Turia del tercer libro de Diana, en que Gaspar Gil Polo pasa revista en tono elogioso a los principales autores de su época, el laurel aparece con frecuencia para coronar a los poetas:

$$
\begin{aligned}
& \text { pues, nymfas, esparzid yerbas y flores } \\
& \text { al grande Jaime Roig agradescidas, } \\
& \text { coronad con laurel, serpillo y apio, } \\
& \text { el gran siervo de Apolo y Esculapio. } \\
& \text { Y el gran Narcís Viñoles, que pregona } \\
& \text { su gran valor con levantada rima, } \\
& \text { texed de verde lauro una corona, } \\
& \text { haziendo al mundo pública su estima }{ }^{47} \text {. }
\end{aligned}
$$

${ }^{44}$ MARQuÉS DE SANTIllanA, «Coronaçión de Mossén Jordi», en Poesías completas, edic. de Manuel Durán, Madrid, Castalia, Clásicos Castalia, 1975, 2 vols., vol. I, p. 163.

${ }^{45}$ Marqués De Santillana, «La Comedieta de Ponza», Ibíd., p. 245.

${ }^{46}$ Poesía de la Edad de Oro. I. Renacimiento, edic. de José Manuel Blecua, Madrid, Castalia, Clásicos Castalia, $3^{a}$ edic., 1986, p. 373.

${ }^{47}$ Gaspar GIL POLO, Diana enamorada, edic. de Rafael Ferreres, Madrid, EspasaCalpe, Clásicos Castellanos, $3^{\text {a }}$ edic., 1973, pp. 151-152. 
$\mathrm{Y}$ antes de iniciar su parlamento, el propio Turia aparece coronado con los emblemas de la fortaleza y de la gloria, transformándose en un híbrido de divinidad fluvial, dios pagano y general victorioso:

\begin{abstract}
No mucho después vimos al viejo Turia salir de una profundíssima cueva, en su mano una urna, o vaso muy grande y bien labrado, su cabeça coronada con hojas de roble y de laurel, los braços vellosos, la barba limosa y encanescida ${ }^{48}$.
\end{abstract}

En el libro VI de su Galatea, Miguel de Cervantes recurre insistentemente al símbolo del laurel para ensalzar a los poetas en un canto, el de Calíope, similar al que Gil Polo introduce en su Diana: «ya la fama canta / del lauro que le tiene aparejado / al licenciado Hernando Maldonado»; Marco Antonio de la Vega aparece con «La sabia frente del laurel honroso / adornada»; a Benito Caldera «prometo honrarte, / y de lauro y de yedra coronarte»; y para otro poeta admirado por nuestro autor:

$$
\begin{aligned}
& \text { Tejed de verde lauro una corona, } \\
& \text { pastores, para honrar la digna frente } \\
& \text { del licenciado Soto Barahona, } \\
& \text { varón insigne, sabio y elocuente }{ }^{49} \text {. }
\end{aligned}
$$

Bajo la aparente seriedad de la composición, descubrimos un tono irónico evidente en el soneto en que Cervantes alaba a Bartolomé Rufino de Chamberí, esclavo del rey de Argel y autor del libro titulado Sopra la desolatione della Goletta, al cual anuncia:

$$
\begin{aligned}
& \text { Del siempre verde lauro coronado } \\
& \text { seréis, si yo no soy mal adivino, } \\
& \text { si ya vuestra fortuna y cruel destino } \\
& \text { os saca de tan triste y bajo estado }{ }^{50} \text {. }
\end{aligned}
$$

Y con el mismo tono irónico que caracteriza a toda la composición, el laurel aparece repetidamente en el Viaje del Parnaso cervantino, para, entre burlas y veras, describir la corte inmortal del dios Apolo y a sus componentes. Así, ya en las páginas autobiográficas con que se inicia el poema:

$$
\begin{aligned}
& \text { Dije entre mí: «Si yo viniese a verme } \\
& \text { en la difícil cumbre de este monte, } \\
& \text { y una guirnalda de laurel ponerme, } \\
& \text { no envidiaría el bien decir de Aponte» }{ }^{51} \text {. }
\end{aligned}
$$

\footnotetext{
${ }^{48}$ Ibíd., p. 144.

${ }^{49}$ Miguel DE CERvantes, La Galatea, en Obras completas, edic. cit., vol. I, pp. 894 , 895 y 897.

${ }^{50}$ Miguel De Cervantes, Poesías sueltas, Ibíd., p. 65.

${ }^{51}$ Miguel De Cervantes, Viaje del Parnaso, Ibíd., p. 73.
} 
A lo largo del poema son varios los escogidos para hallarse junto a Apolo, entre ellos don Fernando Bermúdez, «que en verdes años se apresura / y corre al sacro lauro» ${ }^{52}$; otro autor, que aunque ocupe un grave oficio, «el lauro y palma lleva, / que Apolo da por honra y beneficio» ${ }^{53}$; o don Luis de Barahona, a quien «del siempre verde lauro una corona, / le ofreció Apolo» ${ }^{54}$; y, junto a ellos, «otro, cuyas sienes ves ceñidas / con los brazos de Dafne en triunfo honroso» ${ }^{55}$. En fin, en los últimos versos, aunque en España sólo haya nueve poetas que merezcan el supremo galardón:

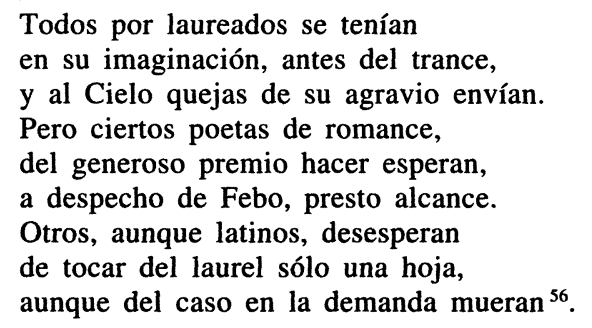

Y el mismo tono chusco emplea Cervantes en el Quijote (II, 18) para referirse a las coronas laurinas. Así, el hidalgo manchego celebra la glosa que recita don Lorenzo con estas palabras:

¡Viven los cielos donde más altos están, mancebo generoso, que sois el mejor poeta del orbe, y que merecéis estar laureado, no por Chipre ni por Gaeta, como dijo un poeta que Dios perdone, sino por las academias de Atenas, si hoy vivieran, y por las que hoy viven de París, Bolonia y Salamanca! Plega al cielo que los jueces que os quitaren el premio primero, Febo los asaetee y las Musas jamás atraviesen los umbrales de sus casas ${ }^{57}$.

Y cuando Sancho está inmovilizado dentro de la sima en que ha caído (II, 55), exclama dirigiéndose a su asno:

Perdóname y pide a la fortuna, en el mejor modo que supieres, que nos saque deste miserable trabajo en que estamos puestos los dos; que yo prometo de ponerte una corona de laurel en la cabeza, que no parezcas sino un laureado poeta, y de darte los piensos doblados ${ }^{58}$.

\footnotetext{
52 Ibíd., p. 80.

${ }^{53}$ Ibíd., p. 81

${ }^{54}$ Ibíd., p. 88.

${ }^{55}$ Ibid., p. 94.

56 Ibíd., p. 114.

${ }^{57}$ Miguel DE CERvanTES, Don Quijote de la Mancha, Ibíd., vol. II, pp. 648.

${ }^{58}$ Ibíd., p. 792.
} 
Las coronas de laurel abundan, lógicamente, en los poemas pensados para ensalzar a artistas y literatos, especialmente los que solían anteponerse a los libros, y que componían para la ocasión los amigos y colegas del autor ${ }^{59}$. Lope de Vega echó repetidamente mano del laurel para alabar a sus contemporáneos ${ }^{60}$, y Laurel de Apolo es el título de la composición en silvas publicada en $1630^{61}$, en la que el autor prodiga alabanzas y coronas entre los escritores de su época, desde, por orden alfabético, el dramaturgo Gaspar de Aguilar o el capitán Francisco Aldana, hasta María de Zayas y Jerónimo Zurita ${ }^{62}$. Incluso Cervantes, que en el prólogo de su Quijote de 1605 confiesa con sorna, por boca del narrador y de su amigo, que los preliminares de su libro han de carecer de sonetos laudatorios compuestos por duques, marqueses, condes, obispos, damas o poetas celebérrimos, y que piensa escribirlos él mismo y achacárselos después al Preste Juan de las Indias o al Emperador de Trapisonda ${ }^{63}$, también tuvo que echar mano del socorrido símbolo de las hojas del laurel en los sonetos que dedicó a las obras de López de Maldonado, del doctor Francisco Díaz, y al marqués de Santa Cruz y su cantor, Mosquera de Figueroa, el cual «al par del griego y escritor toscano / sus sienes ciñe con la verde planta» ${ }^{64}$. En fin, si nos trasladamos al terreno de las artes plásticas, los retratos de poetas coronados de laurel son innumerables durante esta época, desde las conocidas imágenes de Virgilio, Petrarca, Bocaccio o Dante, hasta los retratos de Camoens, Herrera, Alonso de Ercilla o Francisco de Quevedo.

${ }^{59}$ Sirva como ejemplo uno de los sonetos que preceden a la Vida de don Gregorio Guadaña, de Antonio Enríquez Gómez, en cuyos últimos versos: «Ganas con el aplauso la victoria / Y por docto, por sabio y elocuente / Apolo de laurel te ha coronado» (Antonio ENRíQUEZ GÓMEZ, El siglo pitagórico y Vida de don Gregorio Guadaña [1644], edic. de Teresa de Santos, Madrid, Cátedra, Letras Hispánicas, 1991, p. 67).

${ }^{60}$ «Humillaráse a vos el laurel solo: / que no serán para la frente vuestra / ni Dafne esquiva ni celoso Apolo», leemos en el soneto 167 de sus Rimas, dedicado al doctor Agustín Tejada (Lope DE VEGA, Obras poéticas, edic. cit., p. 123); y en La Filomena, aunque con expresión más retorcida: «y así del doctor Peña la corona, / con que Apolo filósofo laurea / su digna frente, en quien mirar desea / el árbol fugitivo, / $\tan$ amoroso ya cuanto era esquivo" (Ibíd., p. 633).

${ }^{61}$ Laurel de Apolo, con otras rimas, por Lope Félix de Vega Carpio, en Madrid, por Iuan Gonçález, 1630.

${ }^{62}$ Garcilaso de la Vega aparece «de mil laureles coronado»; «Tú Minerva, también con manos largas / de Diego Bosque y de Gaspar de Vargas / ciñe las frentes de la verde esfera»; el poeta Tomás Gracián es «del laurel pretendido partícipe»; don Juan Ruiz de Alarcón «aspira / con dulce ingenio a la divina rama»; «y la frente espaciosa / ceñida de laurel tenga Espinosa» (Lope DE VEGA, «Laurel de Apolo», en Colección escogida de obras no dramáticas, edic. de Cayetano Rosell, Madrid, Atlas (Biblioteca de Autores Españoles, 38), 1950, pp. 185-229).

${ }^{63}$ Miguel DE CERVANTES, Don Quijote de la Mancha, en Obras completas, edic. cit., vol. II, pp. 302-303.

${ }^{64}$ Miguel DE Cervantes, Poesías sueltas, Ibíd., vol. I, pp. 48 y 51. 


\section{EL LAUREL, ESCUDO CONTRA LOS RAYOS}

La idea de que el laurel posee virtudes milagrosas y simboliza la inmortalidad, sobrevivió al mundo clásico, y ha llegado hasta nosotros a través de la creencia supersticiosa según la cual las ramas de este árbol proporcionan una protección infalible contra el rayo. Ya entre los romanos, según nos refiere Cayo Plinio, el laurel era venerado, además de por su condición de árbol sagrado, «porque de todos los árboles que se plantan por mano, y se ponen en las casas, sólo éste no es herido de rayo», por lo cual «cuentan que el Emperador Tiberio, quando el Cielo tronaua, acostumbró coronarse de laurel contra el temor de los rayos» ${ }^{65}$; una creencia que San Isidoro recogió y transmitió en sus Etimologías (XVII, 7, 1) ${ }^{66}$, y que Petrarca apunta en su Cancionero, en una composición en que su amada Laura y las ramas del laurel se asocian, no sólo por similitudes fónicas y etimológicas, como veremos después, sino también porque la honestidad de una y el verdor del otro siempre están intactos, a salvo de inclemencias $\mathrm{y}$ agresiones ${ }^{67}$.

Ya en nuestro Renacimiento, según explica el doctor Andrés Laguna, «todos los escriptores confirman que el laurel jamás fue, ni puede ser, herido de rayo: por donde Tiberio César, siempre que sentía tronar, se ponía en la cabeça una guirnalda Laurina» ${ }^{68}$. En la misma época, Pedro Mexía alaba «la propriedad maravillosa deste árbol, que naturalmente es enemigo del fuego y que no puede ser herido con rayo» ${ }^{69}$; Sebastián de Covarrubias recuerda cómo «entre otros privilegios que dio naturaleza al laurel, es uno (según la común opinión) que jamás ha sido tocado del rayo» ${ }^{70}$; y ya en 1513, Gabriel Alonso de Herrera, siguiendo a Plinio, explica que los laureles:

Son árboles muy hermosos que continuamente están verdes, son sus hojas muy oloriosas, adornan mucho los jardines, las claustras de religiosos y los patios de las casas, y aún en las tierras o lugares onde suelen caer rayos los suelen

\footnotetext{
${ }^{65}$ Cayo Plinio Segundo, Historia natural, lib. XV, cap. 30, edic. cit., vol. II, p. 80. Veáse también J. ChEVAliER Y A. GHEERBRANT, Diccionario, p. 630.

${ }^{66}$ «Sola quoque haec arbor vulgo fulminari minime creditur» (SAN ISIDORO DE SEVILlA, Etimologías, edic. cit., vol. II, p. 338).

${ }^{67}$ «et come in lauro foglia / conserva verde il pregio d'onestade, / ove non spira folgore, né indegno / vento mai che l'aggrave» [«y verde guarda / su honestidad como el laurel las hojas, / donde no caen rayos, ni los vientos / jamás han de troncharla»] (Francesco PETRARCA, «Canción XXIX», Cancionero, edic. cit., vol. I, pp. 206-207).

${ }^{68}$ Andrés Laguna, Pedacio Dioscórides, edic. cit., vol. I, p. 65.

${ }^{69}$ Pedro MeXía, Silva de varia lección [1550-1551], I, 33, edic. de Antonio Castro, Madrid, Cátedra, Letras Hispánicas, 1989, 2 vols., vol. I, p. 461.

${ }^{70}$ Sebastián DE CovarRubias, Tesoro, p. 754.
} 
plantar, porque onde ellos están no cae rayo alguno, y por esso el emperador Tiberio, cuando tronaba se ponía una guirnalda de laurel en la cabeza por estar seguro de rayos $^{71}$.

Las creencias acerca del laurel como árbol protector contra los rayos, fueron aprovechadas con frecuencia en el teatro y la lírica de los siglos XVI y XVII, aunque con fines expresivos muy diversos. Así, en Los balcones de Madrid, de Tirso de Molina, la protagonista, Elisa, pese al rigor de su padre, se siente firme y esperanzada en su amor, como el laurel frente al rayo:

$$
\begin{aligned}
& \text { Instantáneo rayo ha sido, } \\
& \text { don Juan, mi padre cruel; } \\
& \text { mas privilégiame dél } \\
& \text { mi firmeza inexpugnable; } \\
& \text { que aunque a todos formidable, } \\
& \text { no hiere el rayo al laurel. } \\
& \text { Cuando de mi amor discuerde } \\
& \text { y me amenacen congojas, } \\
& \text { no porque tiemblen las hojas, } \\
& \text { el laurel su verdor pierde. } \\
& \text { Siempre firme, siempre verde } \\
& \text { sus rigores me verán; } \\
& \text { y si en perseguirme dan, } \\
& \text { morir es total remedio; } \\
& \text { que mi amor no admite medio } \\
& \text { entre la muerte y don Juan }{ }^{72} .
\end{aligned}
$$

En El desdén con el desdén, Agustín Moreto establece un parangón entre la leyenda de Apolo y Dafne, la ninfa convertida en laurel para que el dios no la pudiera alcanzar, y las tribulaciones del protagonista, Carlos, conde de Urgel, que teme ser rechazado por Diana, de la que vive enamorado en secreto. En la canción que los músicos entonan en presencia de ésta última, la ninfa Dafne queda doblemente protegida contra el deseo del dios, en primer lugar por su mágica transformación en laurel, y también por ser las ramas del árbol un escudo infalible contra el rayo, al que Apolo queda asimilado de manera metafórica:

$$
\begin{aligned}
& \text { Huyendo la hermosa Dafne, } \\
& \text { burla de Apolo la fee; } \\
& \text { sin duda la sigue un rayo, } \\
& \text { pues la defiende un laurel }{ }^{73} \text {. }
\end{aligned}
$$

\footnotetext{
${ }^{71}$ Gabriel Alonso DE HERRERA, Obra de agricultura, edic. de José Urbano Martínez Carreras, Madrid, Atlas (Biblioteca de Autores Españoles, 235), 1970, p. 166.

${ }_{72}$ TIRSO DE MolinA, Los balcones de Madrid, jornada I, escena 4, en Comedias escogidas, edic. de Juan Eugenio Hartzenbush, Madrid, Atlas (Biblioteca de Autores Españoles, 5), 1944, p. 556.

${ }^{73}$ Agustín MoReto, El desdén, con el desdén, acto I, escena 4, en Obras, edic. de Luis Fernández Guerra, Madrid, Atlas (Biblioteca de Autores Españoles, 39), 1950, p. 4.
} 
En la segunda parte de La hija del aire, de Calderón de la Barca, es la espada del general Friso la que se convierte en rayo cuando amenaza la cabeza del rey Ninias, a la que de nada servirán como protección — dicelos laureles de su corona e imperio:

$$
\begin{aligned}
& \text { Hijo de la guerra soy, } \\
& \text { y sabrá darme la guerra } \\
& \text { ocasiones en que Ninias } \\
& \text { conozca que esta sangrienta } \\
& \text { cuchilla es rayo tan fuerte, } \\
& \text { que ningún laurel respeta, } \\
& \text { y podrá ser que amenace, } \\
& \text { tal vez, el de su cabeza }{ }^{74} \text {. }
\end{aligned}
$$

Una imagen similar utilizó Quevedo, quien, al recordar la ruina del Imperio Romano en un soneto, dirigiéndose a la ciudad de Roma, le advierte:

$$
\begin{aligned}
& \text { El laurel que te abraza las dos sienes } \\
& \text { llama al rayo que evita, y peligrosas } \\
& \text { y coronadas por igual las tienes }{ }^{75} \text {. }
\end{aligned}
$$

El mismo autor, cuando recrea la fábula de Apolo y Dafne, también concluye recordando el verdor perpetuo del laurel y su invulnerabilidad frente a la fuerza del rayo:

$$
\begin{aligned}
& \text { Y viendo caso tan tierno, } \\
& \text { digno de renombre eterno, } \\
& \text { la reservó en aquel llano, } \\
& \text { de sus rayos el verano, } \\
& \text { y de su yelo el invierno }{ }^{76} \text {. }
\end{aligned}
$$

Ya don Juan de Arguijo, al recrear el mito de Apolo y Dafne, pone en boca del dios estas palabras dirigidas a la ninfa:

$$
\begin{aligned}
& \text { Del ardiente rayo vivirás segura, } \\
& \text { que no es bien que consienta ajeno fuego } \\
& \text { quien pudo resistir al fuego mío }{ }^{77} \text {. }
\end{aligned}
$$

$Y$ en una versión burlesca del mito, a la que luego nos referiremos, Jacinto Polo de Medina concluye recordando cómo el dios contempla la transformación de la ninfa:

\footnotetext{
${ }^{74}$ Pedro Calderón de la BARCA, La hija del aire. Segunda parte, jornada II, escena IV, en Obras, edic. cit., vol. III, p. 54.

${ }^{75}$ Francisco DE QUEVEDo, Poesía, edic. cit., p. 87.

76 Ibid., p. 253.

${ }^{77}$ Juan DE ARGUIJO, Obra poética, edic. cit., p. 73.
} 


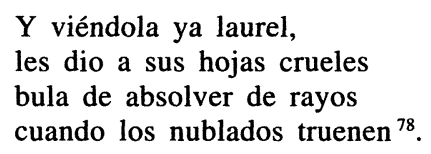

La idea de que el laurel protege contra los rayos fue una creencia arraigada, como puede comprobarse, y en versiones ya vulgarizadas ha llegado hasta nosotros a través de la superstición que ve en las ramas del árbol un amuleto eficaz contra las inclemencias de los cielos. Tal creencia ha pervivido en ambientes rurales hasta nuestros días, y aparece documentada en Cataluña por Joan Amades, quien comenta la costumbre de plantar laureles a la puerta del hogar, «perquè protegeixen la casa contra els llamps, esquiven les bruixes, els mals esperits i els lladres i porten ventura i fortuna en gran» ${ }^{79}$. Si bien la superstición pagana se ha cristianizado, como tantas otras, y las cualidades mágicas del árbol se atribuyen, no a sus virtudes intrínsecas, sino al hecho de que sus ramas sean bendecidas cada Domingo de Ramos junto con las del olivo ${ }^{80}$.

\title{
6. EL LAUREL Y LOS AMBIENTES BUCÓliCOS
}

Entre los romanos, el laurel era el árbol propio del general victorioso y el poeta épico, mientras que la hiedra era la enseña del poeta lírico y bucólico:

\author{
...accipe jussis \\ Carmina coepta tuis, atque hanc sine tempora circum \\ Inter uictrices hederam tibi serpere laurus.
}

Escribe Virgilio en las Bucólicas (VIII, 11-13) ${ }^{81}$, dirigiéndose, supuestamente, a Cayo Asinio Polión. También en la invocación-dedicatoria diri-

\footnotetext{
78 Jacinto POLO DE MEDINA, «Fábula de Apolo y Dafne. Burlesca», en Poesías. Hospital de incurables, edic. de Francisco J. Díez de Revenga, Madrid, Cátedra, Letras Hispánicas, 1987, p. 229.

${ }^{79}$ Joan AMADES, Folklore de Catalunya, Barcelona, Biblioteca Selecta, 1969, 3 vols, vol. III, p. 1112.

${ }^{80}$ Cels GomIS, Botànica popular, Barcelona, L'Avenç, 1891, p. 109; y Joan AMADES, Costumari Català. El curs de l'any, Barcelona, 1950-1956, y edic. facsímil, Barcelona, Salvat Editores y Edicions 62, 1982-1983, 5 vols., vol. II, pp. 688 y ss.

${ }^{81}$ «....recibe este poema comenzado siguiendo tu mandato y deja que alrededor de tus sienes trepe esta hiedra mezclada con los laureles de tu victoria» (Oeuvres de Virgile. Texte latine, edic, cit., p. 62; y Publio VIRGILIO MARÓN, Bucólicas. Geórgicas, edic, cit., p. 205). Fray Luis traduce: «al vencedor laurel, que resplandece / en torno de tu frente y la hermosea, / consiente que, allegada y como asida, / aquesta yedra vaya entretejida» (FRAY LUIS DE LEÓN, en Obras completas., vol. II, p. 865). Véanse también las notas de Bienvenido Morros, en la edición de las obras de Garcilaso citada (p. 458), en que el autor aporta muchos otros ejemplos de los autores latinos referentes a la utilización de la hiedra para coronar al poeta lírico, y del laurel para el épico.
} 
gida a don Pedro de Toledo, virrey de Nápoles, al comienzo de la Égloga primera, Garcilaso, siguiendo a Virgilio, contrapone el laurel que corona a los guerreros invictos, emblema del cantar épico, a la humilde yedra, propia de la poesía lírica y de los ambientes rústicos y pastoriles en que su historia se va a desarrollar:

$$
\begin{aligned}
& \text { el árbol de victoria } \\
& \text { que ciñe estrechamente } \\
& \text { tu glorïosa frente } \\
& \text { dé lugar a la hiedra que se planta } \\
& \text { debajo de tu sombra y se levanta } \\
& \text { poco a poco, arrimada a tus loores; } \\
& \text { y en cuanto esto se canta, } \\
& \text { escucha tú el cantar de mis pastores }{ }^{82} \text {. }
\end{aligned}
$$

La misma idea la reseña Hérrera en su comentario a Garcilaso:

\begin{abstract}
Coronábanse de laurel los poetas heroicos, como se puede ver en Horacio y Estacio, y de mirto los eróticos, que son los que escriben cosas de amor. Pero la corona de hiedra se daba a los poetas menores, que son los no heroicos, que éstos se nombran mayores. Ésta es de los líricos, según algunos, mas no es de toda hiedra, sino de la negra, que tiene la flor de color de azafrán, y las hojas no muy oscuras y teñidas, y llena de grandes racimos ${ }^{83}$.
\end{abstract}

Sin embargo, la presencia del laurel no es rara en los textos de carácter bucólico de la época renacentista, tanto églogas como libros de pastores, y así sus ramas, aunque en el mundo antiguo fueran el emblema del triunfo militar y de la gloria que se alcanza por las letras, en el Renacimiento vinieron a formar parte, junto a otros ornamentos vegetales, del atavío con que los artistas acostumbran a representar a los protagonistas de relatos pastoriles, o los ambientes en que se desenvuelven sus historias. Así, en la Égloga de Plácida y Victoriano, de Juan del Encina, cuando el pastor Gil saluda a sus amigos, les ofrece enseñas que denotan respectivamente triunfo, gloria, vitalidad, fortaleza: «Palma, lauro, yedra y roble / os den por corona y ramo» ${ }^{84}$. En la Égloga II de Garcilaso de la Vega, cuando el pastor Albanio está decidido a abandonar este mundo, ruega a las montañas, los prados y a la corriente del río:

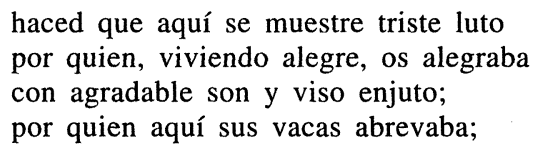

\footnotetext{
${ }^{82}$ GARCILASO DE LA VEGA, Obra poética, edic. cit. p. 122.

${ }^{83}$ Garcilaso de la Vega y sus comentaristas, edic. cit., p. 477.

${ }^{84}$ Juan DEL EnCINA, Teatro completo, edic. de Miguel Ángel Pérez Priego, Madrid, Cátedra, Letras Hispánicas, $2^{\text {a }}$ edic., 1998, p. 289.
} 
por quien, ramos de lauro entretejiendo, aquí sus fuertes toros coronaba ${ }^{85}$.

En los libros de pastores, los personajes suelen llevar en las manos o en la cabeza guirnaldas, coronas y otros ornamentos vegetales que, además de recordar constantemente al lector el ambiente rústico, e idealizado al mismo tiempo, en que los hechos suceden, pueden adquirir, en el contexto de la narración, un particular significado simbólico, similar al que hemos señalado en páginas precedentes. Así, en el libro II de la Galatea de Cervantes, los pastores Damón y Tirsi, poco antes de recitar su canción, aparecen adornados con la enseña de la gloria poética: «venían de verde laurel y fresca yerba coronados» ${ }^{86}$. En el libro III, cuando los pastores están reunidos en alegre fiesta, por un lado de la plaza aparecen los jóvenes Francenio y Lauso, y con ellos «el anciano Arsindo, el cual venía en medio de los dos pastores con una hermosa guirnalda de verde lauro en las manos», tejida para premiar a quien triunfe en la competición poética que sus dos acompañantes entablarán a continuación ${ }^{87}$. Y en el libro VI, la ninfa Calíope, antes de entonar, como musa de la poesía, su conocida canción en loor de los poetas del periodo, se presenta ante los pastores coronada de laurel, en las manos sendos ramos cuya significación nos explica el narrador:

...por las espaldas traía esparcidos los más luengos y rubios cabellos que jamás ojos humanos vieron, y sobre ellos una guirnalda sólo de verde laurel compuesta; la mano derecha ocupaba con un alto ramo de amarilla y vencedora palma, y la izquierda con otro de verde y pacífica oliva, con los cuales ornamentos tan hermosa y admirable se mostraba, que a todos los que la miraban tenía colgados de su vista ${ }^{88}$.

En el «Romance del nacimiento», que Lope incluyó en sus Rimas sacras, las palmas, coronas y laureles son, en manos de los pastores, el mejor homenaje para el recién nacido:

\footnotetext{
Ramos en las manos llevan, y coronados de flores, por la nieve forman sendas cantando alegres canciones. Llegan al portal dichoso
}

\footnotetext{
${ }^{85}$ Garcilaso de la VeGa, Obra poética, edic. cit., p. 173. Como ha indicado Bienvenido Morros (Ibíd., p. 489), las coronas que ciñen las cabezas de los toros recuerdan a las ínfulas y guirnaldas con que se adornaba a las víctimas de los sacrificios en el mundo clásico.

${ }^{86}$ Miguel DE Cervantes, La Galatea, en Obras completas, edic. cit., vol. I, p. 772.

87 Ibíd., p. 818.

${ }^{88}$ Ibíd., p. 891.
} 


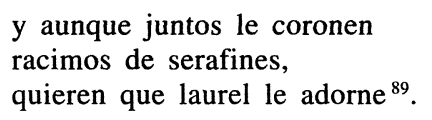

En una de las canciones amorosas de Quevedo, como en tantas otras del Renacimiento y el Barroco, la historia se traslada a un ambiente pastoril en que el protagonista, «exento del amor», sólo halla consuelo para sus penas en la naturaleza, que siempre le acompaña y a la que puede comunicar su dolor, y en ese ambiente:

$$
\begin{aligned}
& \text { Hoy ceñí mi cabeza con laureles, } \\
& \text { tejiendo a mi placer una guirnalda; } \\
& \text { por calles de jacinto y esmeralda, } \\
& \text { envuelto en pobres pieles, } \\
& \text { sin yugo de.dolor, con pasos tardos, } \\
& \text { cortaba flores y arrancaba cardos }{ }^{90} \text {. }
\end{aligned}
$$

En las fiestas de inspiración bucólica protagonizadas por nobles, tampoco suelen faltar los laureles: Así, en el episodio de la fingida Arcadia del Quijote (II, 58), los protagonistas encuentran a dos hermosísimas jóvenes, vestidas como pastoras, que «traían los cabellos sueltos por las espaldas, que en rubios podían competir con los rayos del mismo sol, los cuales se coronaban con dos guirnaldas, de verde laurel y de rojo amaranto tejidas» ${ }^{91}$. En el tercero de los Cigarrales de Toledo, caballeros y damas se entretienen con alegres e inocentes pasatiempos que recuerdan algo a la fingida Arcadia cervantina:

\footnotetext{
No durmieron todos, pues unos jugando ajedrez, otros trucos y tablas, y algunas damas cogiendo flores, tejiendo guirnaldas y cantando letras, ahorraron el sueño para la noche, porque con más aliento satisfaciesen por junto aquel ayuno. Las tres serían cuando acabaron de comer, y cerca de las cinco cuando don Juan entró a despertar los varones y Lisida a las damas, agradeciéndoselo unos y otras. [...] Hizo don Juan que, coronada la Peregrina hermosa de jazmines y claveles, se asentase en la suprema silla, y a sus lados, él y su querida prenda, con guirnaldas: Lisida, de murta, retama y madreselva, y don Juan de laurel ${ }^{92}$.
}

E incluso Fray Luis de León parece descubrir en las hojas del laurel, no sólo el emblema de la creación poética y la gloria literaria, sino también el símbolo de una utopía bucólica, presente en los libros de pastores,

\footnotetext{
${ }^{89}$ Lope DE VEGA, Obras poéticas, edic. cit., p. 534.

${ }^{90}$ Francisco DE QuEvedo, Poesía, edic. cit., p. 418.

${ }^{91}$ Miguel DE CERVANTES, Don Quijote de la Mancha, en Obras completas, edic. cit., vol. II, p. 803.

${ }_{92}$ TIRSO DE MOlinA, Cigarrales de Toledo, edic. cit., p. 355.
} 
que sueña con el retorno a la naturaleza, y que aspira a restaurar, al menos mediante la imaginación, una primitiva Edad de Oro ideal ${ }^{93}$.

\section{LAUREL Y LOCUS AMOENUS}

El laurel, de otro lado, por su belleza y su verdor perennes, suele formar parte de los paisajes ideales o locus amoenus de la Antigüedad, la Edad Media y el Renacimiento, un aspecto señalado por Curtius en su estudio clásico ${ }^{94}$. Petronio, por ejemplo, lo incluye en una de las primeras descripciones modélicas de este tipo en la literatura latina ${ }^{95}$. Como árbol de la poesía épica, y como componente de los lugares amenos, el laurel preside el escenario en que acampan o combaten los ejércitos en los relatos medievales de carácter épico, como el Libro de Alexandre, según vimos, y así ocurre también en la lírica, y sobre todo en la literatura pastoril del Renacimiento. En el segundo libro de la Diana de Montemayor, por ejemplo, Sireno y Selvagia oyen la melodiosa canción que entonan tres hermosas ninfas, cuya voz les parece que procede del «prado de los laureles, por donde pasa el arroyo que corre de esta clara fuente» ${ }^{96}$. En el libro VI, cuando Sireno sale de su aldea hacia la fuente de los alisos, con la intención de encontrar a Selvagia o a Silvano, «antes que llegase a la fuente en medio del verde prado, que de mirtos y laureles rodeado estaba, halló las ovejas de Diana, que solas por entre los árboles andaban paciendo so el amparo de los bravos mastines» ${ }^{97}$. Y Cervantes, en el libro VI de su Galatea y por boca del pastor Elicio, recrea a orillas del Tajo una verdadera Arcadia en que tampoco están ausentes los laureles:

De sus cultivados jardines, con quien los huertos Hespérides y de Alcinoo pueden callar; de los espesos bosques, de los pacíficos olivos, verdes laureles

${ }^{93}$ «A la sombra tendido / de yedra y lauro eterno coronado, / puesto el atento oído / al son dulce, acordado, / del plectro sabiamente meneado» (FRAY LUIS DE LEÓN, «Vida retirada», en Obras completas, edic. cit., vol. II, p. 745).

${ }^{94}$ Ernst Robert CURTIUS, Literatura europea, pp. 280 y ss.

${ }^{95}$ «Mobilis aestiuas platanus diffuderat umbras / et bacis redimita Daphne tremulaeque cupressus / et circum tonsae trepidanti uertice pinus. / Has inter ludebat aquis errantibus amnis / spumeus, et querulo uexabat rore lapillos. / Dignus amore locus» [«El movedizo plátano había extendido sus sombras estivales y Dafne, coronada de bayas, y los trémulos cipreses y los pinos de contorno recortado con su copa ondulante. Por en medio un arroyuelo retozaba con sus aguas vagantes cubierto de espuma y batía la arena con sus quejumbrosas ondas. Rincón hecho para el amor»] (Petronio ÁRBITRO, Satiricón, cap. CCCXXXI, edic. de Manuel C. Díaz y Díaz, Barcelona, Ediciones Alma Mater, Colección Hispánica de Autores Griegos y Latinos, 1968, 2 vols., vol. II, pp. 136-137).

${ }^{96}$ Jorge DE MONTEMAYOR, La Diana, edic. de Juan Montero, Barcelona, Crítica, Biblioteca Clásica, 1996, p. 73

${ }^{97}$ Ibíd., p. 258. 
y acopados mirtos; de sus abundosos pastos, alegres valles y vestidos collados, arroyos y fuentes que en esta ribera se hallan, no se espere que yo diga más, sino que si en alguna parte de la tierra los Campos Elíseos tienen asiento, es, sin duda, en ésta ${ }^{98}$.

Ese paisaje ideal también puede situarse en un lugar muy apreciado por los poetas de la Edad Media y el Renacimiento, el jardín, un recinto en que el hombre ha conseguido una sabia combinación de naturaleza y artificio ${ }^{99}$, y en que todo invita a perfeccionar y recrear los sentidos, gozar del amor y disfrutar de la belleza natural. Así ocurre en el escenario alegórico descrito en la primera parte del Roman de la rose ${ }^{100}$. En la canción LXIX de Francisco de Figueroa, se nos dice que, junto al primitivo muro de Roma, «tienen un verde y deleitoso prado / las manos de Natura artificiosas, / siempre de varias flores esmaltado», al cual «un cielo de laureles le defiende / del sol, que quiere ver todas las cosas», y allí, «debajo de un laurel tendido, / Tirsi al son de la cítara cantaba / del fruto amargo del amor seguido» ${ }^{101}$. Y en el capítulo III de su Viaje del Parnaso, Cervantes describe un jardín alegórico, el de Apolo, en que el arte y la naturaleza parecen «andar en competencia, y está en duda / cual vence de las dos, cual más merece» ${ }^{102}$. Aquel espacio ideal, «junto con ser jardín, era una huerta, / un soto, un bosque, un prado, un valle ameno» ${ }^{103}$, y en él se encuentran todas las especies vegetales con que los antiguos dioses premiaban a los poetas: la pacífica oliva, el glorioso laurel, la palma de la victoria, la hiedra que corona a los poetas líricos, el mirto de Venus, propio de la poesía erótica, el cedro del poeta épico, y el poderoso roble, símbolo de fortaleza. Antes de penetrar en el sagrado recinto, y tras acercarse a las fuentes de Castalia, Aganipe e Hipocrene, los componentes del escuadrón apolíneo «Beben, y suben por el monte arriba, / por entre palmas, y entre cedros altos, / y entre árboles pacíficos de oliva» ${ }^{104}$. Y ya en el jardín del Parnaso:

\footnotetext{
${ }^{98}$ Miguel DE CERvanTES, La Galatea, en Obras completas, edic. cit., vol. I, p. 885

${ }^{99}$ Veáse Terry COMITO, The Idea of the Garden in the Renaissance, New Brunswick N. J., Rutgers University Press, 1978.

${ }_{100}$ «De grandes laureles y elevados pinos / estaba repleto todo aquel jardín, / sin faltar tampoco olivos, cipreses / (los cuales no existen apenas aquí), / ni los altos olmos, muy grandes y espesos: / había asimismo adelfas y hayas, / y encinas y fresnos, y álamos temblones, / y abetos y arces, y robles también» (Guillaume DE LORRIS / Jean DE MEUnG, Roman de la rose, edic. y traduc. de Juan Victorio, Madrid, Cátedra, Letras Universales, 2. a edic., 1998, p. 78, versos 1353-1360).

${ }^{101}$ Francisco DE FigueroA, Poesía, edic. de Mercedes López Suárez, Madrid, Cátedra, Letras Hispánicas, 1989, pp. 186-187.

${ }^{102}$ Miguel DE CERvanTes, Viaje del Parnaso, en Obras completas, edic. cit., vol. I, p. 89.

${ }^{103}$ Ibíd.

${ }^{104}$ Ibíd.
} 


\begin{abstract}
Llegaban los laureles casi a ciento, a cuya sombra y troncos se sentaron algunos de aquel número contentos. Otros los de las palmas ocuparon, de los mirtos y hiedras, y los robles también varios poetas albergaron ${ }^{105}$.
\end{abstract}

En fin, volviendo al ambiente de las églogas y relatos pastoriles, señalaremos que el laurel aparece de manera ocasional en ceremonias o recintos funerarios, o en composiciones de carácter elegíaco, en que, sin perder el significado que le es propio - el triunfo y la gloria artísticos-, también denota, igual que otras especies vegetales presentes en tales ámbitos, las ideas de paz, recuerdo, permanencia e inmortalidad del alma ${ }^{106}$; y en este sentido es interesante recordar que, mientras que en la tradición católica, el sauce, la palmera, el roble, el olmo, y sobre todo el ciprés, son árboles típicos de los cementerios ${ }^{107}$, en la Antigüedad debió de ser corriente la presencia del laurel con los mismos fines ${ }^{108}$. Así, en el libro IV de la Diana de Montemayor, los personajes que visitan el palacio de Felicia, llegan hasta un jardín en que reposan para siempre las mujeres que, por su inmaculada castidad, imitaron a Diana, y en cuyos sepulcros, junto a plantas como el arrayán, consagrado a Venus, no faltan los laureles, para recordarnos el triunfo de su virtud. Se trata de:

... un hermoso jardín, cuya vista no menos admiración les causó que lo que hasta allí habían visto; entre cuyos árboles y hermosas flores había muchos sepulcros de ninfas y damas, las cuales habían con gran limpieza conservado la castidad debida a la castísima diosa. Estaban todos los sepulcros coronados de enredosa yedra; otros de olorosos arrayanes, otros de verde laurel ${ }^{109}$.

Y en la égloga que Fernando de Herrera dedica a la muerte de Amarilis, las especies vegetales propias de la tradición cristiana aparecen suplantadas por otras de claro sabor pagano:

A ti te dará Apolo a ruego mío su lauro siempre verde y consagrado; darán faunos las vides adornadas de rramos y cloror entremesclado ${ }^{110}$.

\footnotetext{
${ }^{105}$ Ibíd., pp. 89-90.

${ }^{106}$ Celestino Barallat, Principios de botánica funeraria, Barcelona, 1885, y edic. facsímil, Barcelona, Altafulla, 1984, pp. 5 y ss.

${ }^{107}$ Ibid., pp. 6 y ss.

${ }^{108}$ Ibíd., p. 24.

${ }^{109}$ Jorge DE MONTEMAYOR, Diana, edic. cit., p. 205.

${ }^{110}$ Fernando DE HERRERA, Poesía castellana original completa, edic. de Cristóbal Cuevas, Madrid, Cátedra, Letras Hispánicas, 2a edic., 1997, p. 307.
} 


\section{El LAUREL, EMBLEMA DEL AMOR}

Mientras que en la poesía cortesana de final de la Edad Media, si exceptuamos algunas cancioncillas y villancicos anónimos reelaborados y glosados en los cancioneros, es poco frecuente la presencia del mundo vegetal como marco en que se expresa el amor, menos aun con un sentido simbólico, y la expresión de los sentimientos se suele desarrollar en un plano conceptual, artificiosos y abstracto, con especial atención a los estados de ánimo, el Renacimiento supondrá una nueva atención al mundo natural, que pasará a formar parte de la trama del poema, a veces con un papel meramente ornamental, en la línea del viejo locus amoenus tan del gusto de los poetas medievales, otras con un planteamiento original, como partícipe y símbolo de los sentimientos del poeta. Y en ello tuvo que ver sin duda el interés de estos autores por la literatura clásica latina y griega, y por los escritores italianos, especialmente Petrarca.

El laurel, en efecto, al menos desde Petrarca, se asocia con el amor por un doble motivo. Para el poeta italiano, el árbol cuyo nombre recordaba al de su amada Laura, se convirtió en el emblema de su devoción sin límites, y como tal puede hallarse en las sutiles paronomasias, metáforas y referencias simbólicas presentes por doquier en sus poemas ${ }^{111}$, y largamente imitadas por sus seguidores ${ }^{112}$. Así ocurre en la composición XXX de su Cancionero, cada una de cuyas seis estrofas contiene la palabra lauro, y que empieza con los versos «Giovene donna sotto un verde lauro / vidi piú bianca et piú fredda che neve» ${ }^{113}$. En la canción CXXIX - «Di pensier in pensier, di monte in monte, / mi guida Amor»-, el laurel y el aura componen un breve locus amoenus y evocan juntos la figura de Laura, tanto por sus connotaciones placenteras como por la similitud fonética que los dos términos tienen con el nombre de la amada: «ove l'aura si sente / d'un fresco et odorifero laureto» ${ }^{114}$. En otra composición, la canción CXLII, perseguido por el calor del estío, el poeta busca refugio bajo gratas frondas - «la dolce ombra de le belle frondi»-, en este caso las del emble-

${ }^{111}$ Véase José BASILE, Forma simbolica ed allegorica nei Rerum vulgarium Fragmenta ed altre cose, Assisi-Roma, Beniamino Carucci Editore, 1971, pp. 45 y ss. y 115 y ss.; John FRECCERO, «The Fig Tree and the Laurel: Petrarchs's Poetics», en Patricia PARKER y David QUINT (eds.), Literay Theory / Renaissance Texts, Baltimore, Johns Hopkins University Press, 1986, pp. 20-32; y Sara STURM-MADDOX, Petrarch's laurels, University Park, Pennsylvania State University, 1992.

${ }^{112}$ María Pilar MANERo SOROlla (Imágenes petrarquistas, pp. 358 y ss.) junto al comentario de los textos de Petrarca que aquí reproducimos, aporta interesantes ejemplos de poetas posteriores italianos y españoles.

${ }^{113}$ Francesco PETRARCA, Cancionero, edic. cit., vol. I, p. 208.

${ }^{114}$ Ibíd., p. 480. 
mático laurel de hermosas ramas: «Non vide il mondo si leggiadri rami», «Un lauro mi difese allor dal cielo» ${ }^{115}$. Y en el soneto CCXXVIII:

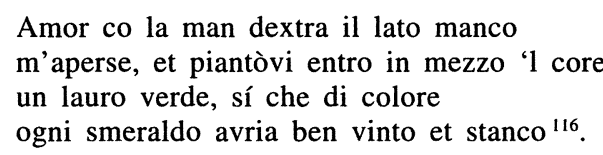

De esta manera el laurel, como emblema de la amada y del amor, pasará a la obra de poetas españoles del Renacimiento como Francisco de Figueroa, en cuyo soneto CV:

$$
\begin{aligned}
& \text { Yo, triste y solo en tierra ajena quedo } \\
& \text { lejos, Arabia, de ti, donde crecía } \\
& \text { en tus riberas y en el alma mía } \\
& \text { el lauro que arrancar quiero y no puedo }{ }^{117} \text {. }
\end{aligned}
$$

O Fernando de Herrera, en cuya sextina I, el lauro es símbolo del amor y la alegría con que el protagonista se coronó en otro tiempo, y cuya pérdida lamenta hoy, igual que el cisne, en un canto triste y dulce:

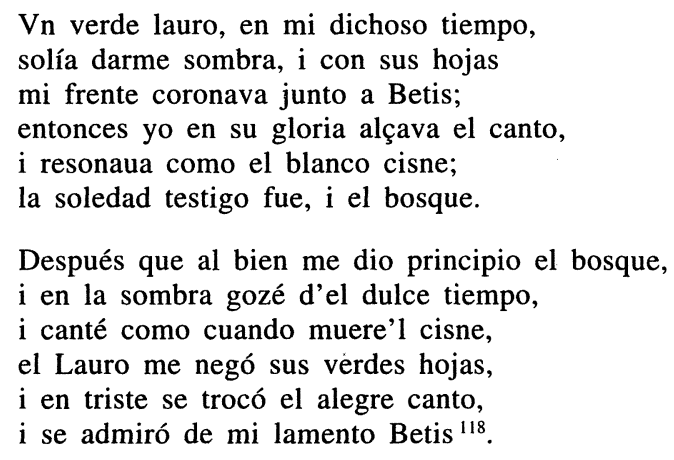

De otro lado, el conocido mito divulgado por Ovidio ${ }^{119}$ en que se explica el origen del laurel, cuyo nombre es $\delta \alpha \dot{\phi} \phi \eta \eta$ en griego, refiere cómo

${ }^{115}$ Ibid., p. 512.

116 «Amor con la derecha mano me abrió el lado / izquierdo, donde allí plantó en el pecho / un tan verde laurel que a la esmeralda / en el color hubiérale vencido» (Ibíd., vol. II, pp. 698-699)

${ }^{117}$ Francisco DE FIGUEROA, Poesía, edic. cit., p. 221.

${ }^{118}$ Fernando DE Herrera, Poesía, edic., cit., pp. 520-521. Para las fuentes y tratamiento del tema en la composición de Herrera, véase Ignacio NAVARRETE, Los huérfanos de Petrarca. Poesía y teoría en la España Renacentista, Madrid, Gredos, Biblioteca Románica Hispánica, 1994, pp. 238 y ss.

${ }^{119}$ Publio Ovidio, Metamorfosis, lib. I, edición y traducción de Antonio Ruiz de Elvira, Madrid, CSIC, Colección Hispánica de Autores Griegos y Latinos, 1982-1984, 3 vols., vol. I, pp. 25-31. 
Apolo, ufano de su victoria sobre la sierpe Pitón, se burló de las armas de hombre adulto que, a pesar de ser un niño, utilizaba Cupido, y cómo éste, para vengarse, hirió a aquél con una flecha de oro, con lo que despertó en su pecho un amor irrefrenable por la ninfa Dafne, mientras que a ésta la hirió con una flecha de plomo, que engendró en ella desvío y aversión. Los ruegos y quejas de Apolo no tuvieron efecto alguno sobre el endurecido corazón de la ninfa, por lo que, desesperado, dio en perseguirla por el bosque, hasta que ella, a punto de ser alcanzada, imploró la ayuda de su padre, el río Peneo, y quedó convertida en un laurel al que Apolo se abrazó llorando, tras lo cual, ya que no logró desposarse con la ninfa y poseer su cuerpo, el desdeñado dios hizo del laurel su emblema y su árbol predilecto, con lo que su historia ha venido a simbolizar el amor triste, mal correspondido o desdichado.

La leyenda fue muy conociḍa en la Edad Media a través de numerosas copias, ediciones y adaptaciones del poema de Ovidio, y la recoge entre otros don Enrique de Villena en su traducción de la Eneida ${ }^{120}$. Al mito de Apolo y Dafne también le dedicaron poemas numerosos autores del Renacimiento y el Barroco ${ }^{121}$, entre ellos Garcilaso ${ }^{122}$, a quien debemos las versiones más conocidas: En su Égloga III, en el tapiz que muestra la ninfa

${ }^{120}$ Enrique DE VILLENA, Traducción y glosas de la Eneida. Libros I-III, en Obras completas, edic. de Pedro M. Cátedra, Madrid, Turner, Biblioteca Castro, 1994, 3 vols., vol. II, pp. 643-644.

${ }^{121}$ Véanse los estudios generales de Gilbert HIGHET, La tradición clásica: influencias griegas y romanas en la literatura occidental, México, FCE, 1954, 2 vols.; y Jean SEZnEC, Los dioses de la Antigüedad en la Edad Media y el Renacimiento, Madrid, Taurus, 1983; así como los trabajos, referentes a España, de José María DE Cossío, Fábulas mitológicas en España, Madrid, Itsmo, 1998, 2 vols. (1 $1^{\mathrm{a}}$ edic., Madrid, Espasa Calpe, 1952); Marcia L. WELlES, Arachne's Tapestry: The Transformation of Myth in Seventeenth Century Spain, San Antonio, Trinity University Press, 1985; Suzanne GuILlou-VARGA, Mythes, mithographies et poésie lyrique au Siècle d'Or espagnol, París, Didier, 1986, 2 vols.; y Rosa ROMOJARO, Las funciones del mito clásico en el Siglo de Oro. Garcilaso, Góngora, Lope de Vega, Quevedo, Barcelona, Anthropos, 1999. La presencia de la fábula de Apolo y Dafne en la literatura y arte occidentales ha sido estudiada por Yves GIRAUD, La fable de Daphné. Essai sur un type de métamorphose végétale dans la littérature et dans les arts jusqu'à la fin du XVII siècle, Genève, Droz, 1969; y en España por Mary E. BARNARD, The Myth of Apollo and Daphne fron Ovid to Quevedo: Love, Agon and the Grotesque, Durham, Duke University Press, 1987.

122 Joan CAmmarata, Mythological Themes in the Works of Garcilaso de la Vega, Madrid, Porrúa Turanzas, 1983, pp. 56 y ss.; Suzanne GuILlou-VARGA, Mythes, mithographies, pp. 241 y ss.; Mary E. BARNARD, The Myth of Apollo and Daphne, pp. 110130; E. ARTigas ÁllvareZ, «Dafne: La metamorfosis de Ovidio en Garcilaso», en José M. ${ }^{a}$ Maestre MAestre y Joaquín Pascual Barea (eds.), Humanismo y pervivencia del mundo clásico. Actas del I Simposio sobre Humanismo y Pervivencia del Mundo Clásico (Alcañiz, 8 al 11 de mayo de 1990), Teruel y Cádiz, Instituto de Estudios Turolenses y Universidad de Cádiz, 1993, 2 vols., vol. I, pp. 295-304; e Ignacio Navarrete, Los huérfanos de Petrarca, pp. 130-133. 
Dinámene, el autor recrea poéticamente la leyenda recogida por Ovidio ${ }^{123}$; $y$ en su soneto XIII, es el protagonista enamorado quien, como el dios ante el laurel que antes fuera hermosa ninfa, acrecienta con el llanto su dolor inextinguible, con lo que la pesadumbre de Apolo y la del propio poeta acaban identificándose:

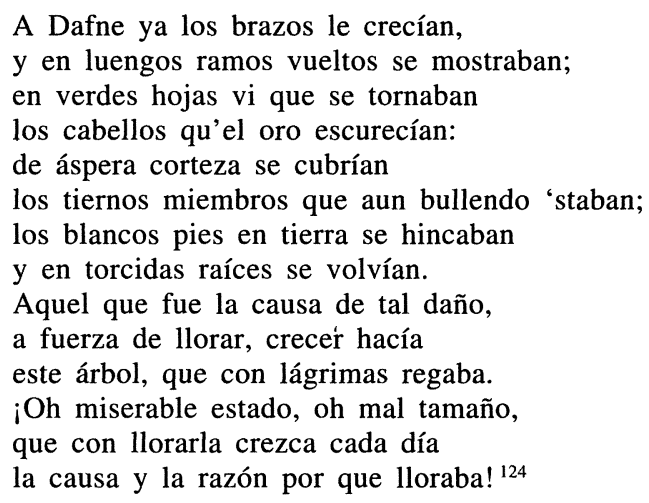

También Diego Hurtado de Mendoza invocó a la:

¡Hermosa Dafne, tú que convertida fuiste en verde laurel de casto miedo, por no esperar aquel que en la huida te había de alcanzar, o tarde o cedo! ${ }^{125}$

Jorge de Montemayor dedicó al mito un soneto en cuyos versos:

Phebo, de amor herido se quexaba de la hermosa Daphne que huía, con sus dorados rayos la seguía y en los suyos della se quemaba.

Como en otras versiones de la leyenda, la ninfa implora la ayuda de Peneo, que «en árbol la convierte y en llegando / el sin ventura Phebo queda frío». Finalmente, como en la versión garcilasiana, el hablante siente que la desgracia del dios es idéntica a la suya, y:

Con el laurel se abraça el desdichado, con lágrimas el tronco está regando: ¿quién tal tormento vio, si no es el mío? ${ }^{126}$

${ }^{123}$ GaRcilaso DE LA VeGA, Obra poética, edic. cit., pp. 231-232.

${ }^{124}$ Ibíd., p. 28.

${ }^{125}$ Diego Hurtado de Mendoza, Poesía completa, edic. cit., p. 8.

${ }^{126}$ Jorge DE MONTEMAYOR, El Cancionero, edic. y prólogo de Ángel González Palencia, Madrid, Sociedad de Bibliófilos Españoles, 1932, pp. 432-433. 
Juan de Arguijo dedicó dos sonetos a las figuras de Apolo y Dafne, según vimos ${ }^{127}$. Gregorio Silvestre incluye entre sus poesías una «Fábula de Dafnes y Apolo» ${ }^{128}$ en versos tradicionales, cuyas imágenes, sin embargo, más que de Ovidio parecen derivar directamente del soneto de Garcilaso citado: Apenas acabada la súplica de Dafne, «cuando los pies que excedían / a la nieve en la blancura, / en raíces se torcían», su hermoso cuerpo «mudarse en tronco se vio / y cubrirse de corteza», y:

$$
\begin{aligned}
& \text { Aquellos brazos tan bellos } \\
& \text { en ramas se convirtieron } \\
& \text { y en las hojas los cabellos } \\
& \text { que con el sol compitieron } \\
& \text { y el triunfo sacaron dellos. }
\end{aligned}
$$

Finalmente Apolo llora abrazado al laurel, que al no haber podido ser su esposa cuando tuvo forma humana, se convertirá en su árbol, y con ello, en signo de triunfo y gloria:

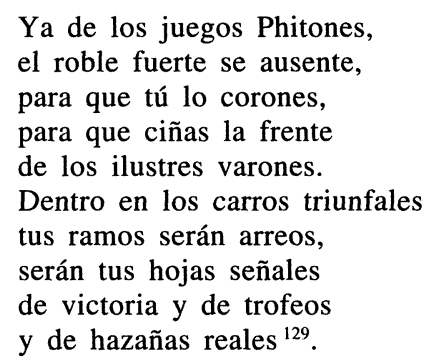

Ya en la centuria siguiente, Manuel de Faria y Sousa desarrolla el mito en una composición en octavas reales, cargada de digresiones mitológicas y alusiones metafóricas de raigambre culterana, en cuyos últimos versos, cuando la metamorfosis acaba de tener lugar, el desdeñado Apolo se lamenta:

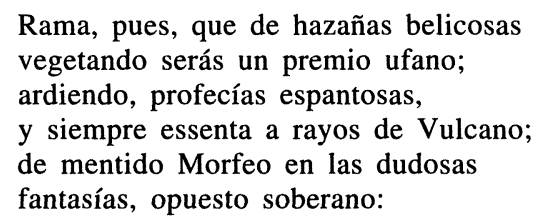

\footnotetext{
${ }^{127}$ Juan DE ARGUIJO, Obra poética, edic. cit., pp. 70 y 73

${ }^{128}$ Gregorio SILVESTRE, «Fábula de Dafnes y Apolo», en Poesías, selección, prólogo y notas de Antonio Marín Ocete, Granada, Universidad de Granada, Publicaciones de la Facultad de Letras, 1938, pp. 178-203.

${ }^{129}$ Ibíd., pp. 201-203.
} 
tanto al mundo serás, al tiempo tanto,

o nieve helada en ti, suelta en mi llanto ${ }^{130}$.

La misma complejidad culterana presenta la «Fábula de Apolo y Dafne» compuesta por el conde de Villamediana ${ }^{131}$, en cuyas últimas estrofas, el laurel, además de quedar libre del furor de las tormentas - «exento honor de siempre rayo impío»-, coronará las sienes del poeta:

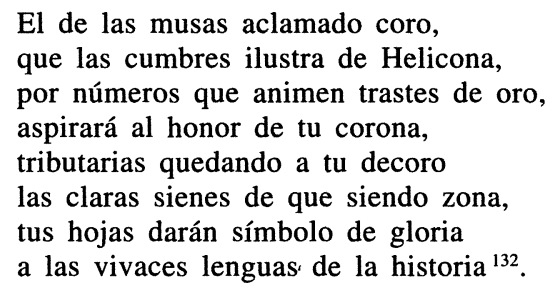

También Calderón compuso para la corte una ópera titulada El laurel de Apolo ${ }^{133}$, en que recrea el mito de Dafne trasladándolo a un ambiente pastoril y envolviéndolo en la refinada atmósfera propia del teatro palaciego. En ella, alternando con digresiones y excursos protagonizados por rústicos y pastores, asistimos a la disputa entre Cupido y Apolo, la venganza que aquél urde con la ayuda de la ninfa Eco, el amor y requerimientos del dios, la persecución, la transformación de Dafne en árbol mediante un sencillo artificio escénico ( $\ll \mathrm{Da}$ vuelta un peñasco con Dafne, y queda a sus espaldas un laurel, con quien se abraza Apolo») y el lamento final del dios, que enumera los atributos y virtudes típicos del árbol:

$$
\begin{aligned}
& \text { Y yo, porque desde aquí } \\
& \text { por sagrado le venere } \\
& \text { el mundo, elijo sus hojas } \\
& \text { para lauro de mis sienes; } \\
& \text { siendo su nombre laurel, } \\
& \text { a quien ni el ábrego hiele, }
\end{aligned}
$$

${ }^{130}$ Manuel DE FARIA Y SouSA, «Fábula de Daphne y Apolo», en Divinas y humanas flores. Primera y segunda parte, Madrid, Diego Flamenco, 1624, fols. 28-42, y fol. 41 v. para el fragmento citado.

${ }_{131}$ Juan DE TASSIS, CONDE DE VILlamedianA, «Fábula de Apolo y Dafne», en Poesía impresa completa, edic. de José Francisco Ruiz Casanova, Madrid, Cátedra, Letras Hispánicas, 1990, pp. 611-646.

${ }^{132}$ Ibíd, p. 643.

${ }^{133}$ Pedro CALDERÓN DE LA BARCA, El laurel de Apolo. Zarzuela en dos jornadas, en Obras, edic. cit., vol. II, pp. 657-671. Véase, a propósito de todo ello, Ángel VALBUENA BRIONES, «El tema del laurel de Apolo en Calderón», en Kurt LEVY y otros, Calderón and the Baroque Tradition, Waterloo (Ontario), Wilfrid Laurier University Press, 1985, pp. 9-21; y José Manuel LosADA GoYA, «Calderón de la Barca: El laurel de Apolo", Revista de Literatura, LI 102, 1989, pp. 485-494. 


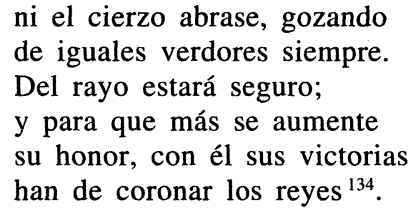

\section{VARIACIONES BURLESCAS}

En fin, concluiremos este recorrido comentando algunas versiones burlescas del mito de Dafne, y de los significados del laurel, en la literatura del siglo XVII; y recordaremos en primer lugar que, frente a la devoción renacentista por los mitos clásicos, y su plasmación idealizada en la literatura y en las artes plásticas de aquel periodo, al artista del Barroco, aficionado a las antítesis y los claroscuros, le gusta contraponer en ocasiones al dios y al héroe de las leyendas antiguas con los antihéroes y seres de carne y hueso que le ofrece el mundo circundante, prosaico y hasta vulgar, y realzar los efectos que tal contraste produce - así lo hace Velázquez con Vulcano y Baco-; o incluso invertir y degradar la imagen y el significado de los mitos y de sus protagonistas, como también ocurre en el retrato velazqueño del dios Marte, quien, tras sus mostachos y con gesto socarrón, observa al espectador con aire desengañado ${ }^{135}$. Como es sabido, en la épica culta de los siglos XVI y XVII, junto a títulos como La Araucana de Alonso de Ercilla, La Austríada de Juan Rufo y La Dragontea de Lope de Vega, hubo versiones paródicas de las hazañas y personajes heroicos, como La Mosquea de José de Villaviciosa o La Gatomaquia, del propio Lope de Vega, y muchas de las leyendas recogidas por Ovidio en su Metamorfosis corrieron la misma suerte.

Ya Pedro Liñán de Riaza, en un romance en que advierte a las damas acerca de los embustes de los buenos y de los malos poetas, había recordado las prosaicas funciones culinarias que el laurel suele cumplir:

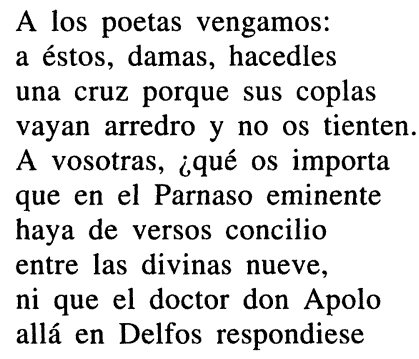

${ }^{134}$ Ibíd., p. 670

${ }^{135}$ Véase Marcia L. Welles, Arachne's Tapestry, pp. 131-166. 


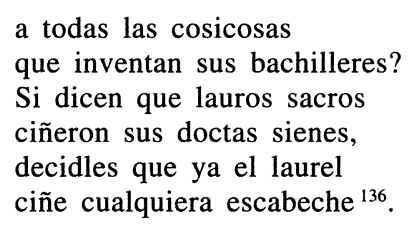

Jacinto Polo de Medina publicó en 1634 su Fábula de Apolo y Dafne. Burlesca, en que la ninfa, tras defenderse con mordiscos de la persecución del dios, exclama indignada:
«Si es que intenta mi ofensa
porque me ve mujer, muy mal lo piensa.
Ráigansele del casco esos intentos,
que me vuelvo laurel y no hay más cuentos».
Pues dicho y hecho fue como lo dijo ${ }^{137}$.

Dafne, en efecto, queda convertida en un laurel, y el decepcionado Apolo lamenta su transformación, al tiempo que le recuerda los humildes menesteres en los que habrá de servir:

$$
\begin{aligned}
& \text { «Oh, qué verde necedad, } \\
& \text { ingrata Dafne, cometes!» } \\
& \text {....................................... } \\
& \text { «Sea laurel quien gustare; } \\
& \text { que no es justo que te empeñes } \\
& \text { en sazonar los pescados } \\
& \text { ni engalanar escabeches. } \\
& \text { En victorias de aceitunas } \\
& \text { sólo a ser corona vienes; } \\
& \text { gentecilla tan soez, } \\
& \text { que en zapateros se vuelven. } \\
& \text { Dirásme, desvanecida, } \\
& \text { que adornarás muchas frentes; } \\
& \text { pero un cuerno hace lo mismo } \\
& \text { en muchas honradas sienes». } \\
& \text { Esto Apolo le decía, } \\
& \text { llorando de veinte en veinte } \\
& \text { las estrellas como el puño; } \\
& \text { y ella se estuvo en sus trece }{ }^{138} \text {. }
\end{aligned}
$$

Lope, que aludió repetidamente a la leyenda de Dafne, y al laurel como signo de la gloria, especialmente en sus Rimas ${ }^{139}$, también tomó el asunto

\footnotetext{
${ }^{136}$ Pedro LiÑán DE RiAZA, Poesías, edic. de Julian F. Randolph, Barcelona, Puvill, 1982, pp. 311-312.

${ }_{137}$ Jacinto POLO DE MEdina, Poesías, edic. cit., p. 227.

${ }^{138}$ Ibíd., pp. 228-229.

${ }^{139}$ Lope DE VEGA, Obras poéticas, edic. cit., sonetos $14,37,67,157$, pp. 31, 45, 62,116 , respectivamente.
} 
por su vertiente burlesca en uno de los sonetos incluidos en las Rimas de Tomé Burguillos, aparecidas el mismo año que la Fábula de Polo de Medina, y en el cual el protagonista, llegado al monte Parnaso, igual que Cervantes en su famoso Viaje, ve a los poetas noveles «pidiendo por principios más laureles / que anima Dafnes y que Apolo cría» ${ }^{140}$; y en otro de los sonetos, el protagonista se empeña en perseguir a la inasequible Juana, como Apolo a Dafne:

Si corres como Dafne y mis fortunas corren también a su esperanza vana, en seguirte anhelantes e importunas, ¿cuándo serás laurel, dulce tirana? Que no te quiero yo para aceitunas, sino para mi frente, hermosa Juana ${ }^{141}$.

Quevedo, por su parte, además de la composición en quintillas antes citada ${ }^{142}$, también escribe un soneto burlesco dedicado «A Apolo siguiendo a Dafne» y otro titulado «A Dafne huyendo de Apolo» ${ }^{143}$, en cuyos últimos versos Dafne huye de la luz de Apolo como si fuera un murciélago, y al fin «en cortezas duras / de laurel se ingirió contras sus tretas, / y, en escabeche, el Sol se quedó a escuras» ${ }^{144}$. El mismo tópico lo aprovecha Calderón en El laurel de Apolo, cuando la villana Bata pone el contrapunto chusco a las virtudes del árbol, que el rubio dios acaba de enumerar: «Y añade que en las batallas / de aceitunas y escabeches / será general» ${ }^{145}$. Y, en fin, entre las composiciones y autores que abundaron en el tema, tiene algún detalle divertido, pese a su escasa originalidad, el romance de Alonso Jerónimo de Salas Barbadillo titulado «Fábula de Apolo y Dafne», aparecido en una antología de José Alfay en $1654^{146}$. La composición se inicia con la venganza que Cupido lleva a cabo tras haberse burlado Apolo de él:

Aquel dios ciego y malsín, preciado de ballestero, causa de tantos achaques

\footnotetext{
${ }^{140}$ Ibid., p. 1340.

${ }^{141}$ Ibíd., p. 1349.

${ }^{142}$ Francisco DE Quevedo, Poesía, edic. cit., pp. 250-253.

${ }^{143}$ Ibíd., pp. 562-563. Para el tratamiento joco-serio de los mitos clásicos en la obra de Quevedo en general, véase Marcia L. WELLES, Arachne's Tapestry, pp. 63-101; y para el de Apolo y Dafne en concreto, Mary E. BARNARD, The Myth of Apollo and Daphne, pp. 131-191.

${ }^{144}$ Ibíd., p. 563.

${ }^{145}$ Pedro CALDERón DE LA BARCA, El laurel de Apolo, jornada II, escena 20, en Obras, edic. cit., vol. II, p. 670.

${ }_{146}$ Alonso Jerónimo DE SAlas BARBadillo, «Fábula de Apolo y Dafne», en Poesías varias de grandes ingenios, recogidas por Joseph Alfay [Zaragoza, Ibar, 1654], edición y notas de José Manuel Blecua, Zaragoza, Institución Fernando el Católico, 1946, pp. 85-86.
} 


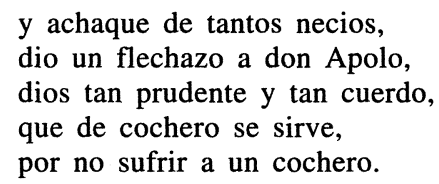

Viene luego el enamoramiento del dios, el cual:

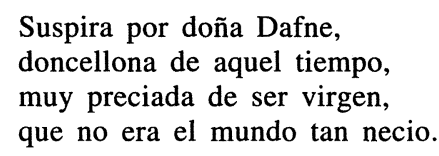

Desdeñado, como en la historia narrada por Ovidio, Apolo da en perseguir a la ninfa, si bien ella:

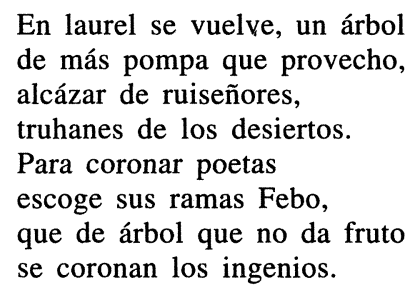

Y el romance concluye recordando al autor de la leyenda, sin que falte el ya manido chiste a propósito de las narices judías, muy del gusto de aquel tiempo:

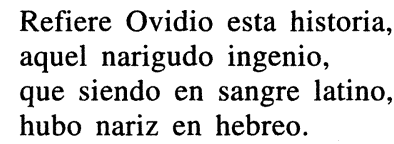

\section{CONCLUSIÓN}

Como recapitulación de lo expuesto en páginas precedentes, valdrá la pena recordar que en la literatura medieval, y sobre todo en la del Siglo de Oro, vuelven a aparecer por doquier los diversos significados que los antiguos asignaron al laurel: árbol consagrado a Apolo, en que se transformó la ninfa Dafne, capaz de preservar de los rayos, o asociado a las artes adivinatorias, la gloria poética y el triunfo militar; mitos y significados transmitidos como parte de un legado culto muy vivo en ambos periodos, que nuestros escritores conocieron a través de la lectura directa de poetas como Virgilio y Ovidio, de tratados científicos como los de Plinio y Dioscórides, de recapitulaciones y fuentes secundarias como las Etimologías de San Isidoro, los Emblemas de Alciato, o manuales de mitología 
como el de Pérez de Moya, muy populares entonces; sin olvidar, claro está, que algunas de esas creencias también se difundieron de forma vulgarizada entre gentes de toda condición, y pervivieron en ciertas supersticiones que han llegado hasta nosotros, y que en la época que hemos estudiado debieron de estar lógicamente muy vivas: Bastará que recordemos, a este respecto, la ya citada opinión acerca de los efectos protectores del laurel frente a las tormentas, presente todavía en el folklore del pasado siglo.

Pero la recepción y el tratamiento del motivo del laurel, y en general de la materia clásica heredada de la Antigüedad, no fue igual en las distintas etapas que hemos estudiado, lo cual quizá aporte nuevos datos para explicar las diferencias que la historia literaria ha señalado entre ellas. Y, en efecto, en la literatura medieval, hasta los primeros destellos del $\mathrm{Hu}$ manismo en el siglo $\mathrm{XV}$, los temas y mitos clásicos, muy difundidos en la enseñanza a través de versiones escolares, antologías o summae, y colecciones de sententiae y exempla, ${ }^{147}$ suelen servir de pretexto para la amplificatio, el excurso ornamental o la erudición postiza, como se advierte a menudo en las obras de Enrique de Villena, Santillana o Juan de Mena, con la salvedad, tal vez, de los nuevos significados del árbol en la obra de Petrarca. En cuanto a los poetas y dramaturgos de los siglos XVI y XVII, pese al frecuente recurso a las hojas del laurel como tópico para significar la gloria y la permanencia, e incluso teniendo en cuenta el tono repetitivo a que obligaba un motivo como éste, sorprende, a pesar de todo, el tratamiento original y las nuevas derivaciones simbólicas que la imagen adquiere en aquel momento: presencia en la literatura bucólica o en las descripciones de paisajes ideales, aprovechamiento de sus significados como expresión figurada de las pasiones maltrechas, con especial referencia al mito de Apolo y Dafne, alusiones repetidas, aunque perfectamente encajadas en poemas y diálogos dramáticos, a la virtud de las ramas como cobijo seguro contra los rayos, etc. Y, en fin, frente a las versiones de mitos y temas clásicos teñidas de idealización y presididas por un deseo de perfección y hermosura, típicas del XVI y presentes todavía en la centuria siguiente, la subversión del Barroco, su tendencia al desengaño y a descubrir la verdad tras las apariencias engañosas, y su empeño en transportarnos, como a Faetón e Ícaro, tan recordados por poetas coetáneos, desde un mundo de bellezas intangibles hasta el duro acontecer terreno, prosaico y hasta vulgar, en que vivimos inmersos: actitudes, todas ellas, que es posible adivinar en aquel tono jocoso que adquieren el mito de Apolo y Dafne y la imagen del laurel en algunos autores del XVII.

${ }^{147}$ Ernst Robert CuRTIUS, Literatura europea, vol. I, pp. 62-96; Francisco LÓPEZ ESTRADA, Introducción a la literatura medieval española, Madrid, Gredos, Biblioteca Románica Hispánica, $5^{a}$ edic., 1983, pp. 117-147. 